Lukas Rösli

\title{
From Schedæ Ara Prests Fróda to Íslendingabók - When an Intradiegetic Text Becomes Reality
}

In this chapter, ${ }^{1}$ I will argue that the text we know today as Íslendingabók was not understood as such in the days of its textualization in the mid-seventeenth century. In fact, Íslendingabók in its present-day manifestation and conception can be regarded as a product of an interaction between different modes of modification. These modes of modification can individually be enumerated as follows: paratextual, medial, scholarly or editorial, and mnemonic. Most of the modifications applied to the text seem to be rather marginal, in the most literal sense, as they mainly affected the title of the text, as well as the narrative's textual, or rather, paratextual framing. Nevertheless, together with the paratextual feature we call the title of a text, the whole notion of the text in question changed tremendously due to the aforementioned modifications. Hence, I will argue that the modification of the title influenced the text's perception on a scholarly level and on the levels of the cultural memory and the national identity that the text produces.

I did not chose Íslendingabók to discuss these modes of modification on the basis of paratexts and paratextual features simply because it is a highly canonized text in the corpus of Old Norse-Icelandic literature or because this is something solely to be found in this specific text. On the contrary, the present study of Íslendingabók can readily be transferred to other texts of the same literary corpus from the "renaissance of Old Norse-Icelandic manuscript production". 2

\footnotetext{
1 The present chapter presents findings from the SNF Ambizione project "Gedächtniskultur im Paratext - Textränder altnordischer Prosahandschriften” (PZ00P1_174231), which is generously funded by the Swiss National Science Foundation. For further information on the project, see www.ds.uzh. $\mathrm{ch} /$ paratext (1 October 2020). I would also like to take this opportunity to thank the two anonymous peer reviewers, whose feedback was extremely valuable.

2 The expression was coined by Jürg Glauser to describe the revival of quasi-medieval manuscript production by scribes in Iceland after the Reformation and after the introduction of the printing press in Iceland, a scribal period between the early seventeenth and the early twentieth century; see Glauser (2016: 21).
}

Lukas Rösli, Humboldt-Universität zu Berlin

¿ Open Access. (C) 2021 Lukas Rösli, published by De Gruyter. (c) BY-NC-ND This work is licensed under the Creative Commons Attribution-NonCommercial-NoDerivatives 4.0 International License.

https://doi.org/10.1515/9783110695366-009 


\section{Background}

\section{Íslendingabók as a historical source}

Íslendingabók, The Book of Icelanders, is considered by scholars as both the oldest known prose text ever written in a Scandinavian language, ${ }^{3}$ and as "a highly concentrated history of the nation" (Jónas Kristjánsson 1997: 120). The nation mentioned by Jónas Kristjánsson is, of course, Iceland, as the story presented in Íslendingabók covers the period of time between the settlement of Iceland around the year 870 up to the days of the first Icelandic bishops at the end of the eleventh and the beginning of the twelfth century.

The content of the text of Îslendingabók is divided into an unmarked prologue, a chapter overview, ten chapters, and two genealogies. ${ }^{4}$ In the prologue, the first-person narrator reports how he wrote Íslendingabók and showed it to the Icelandic bishops porlákr and Ketill and to the priest Sæmundr, who rejected the first version because of the genealogies and reigns of kings it contained. However, after the topos-like call for improvement of the text by people who have more knowledge of the subject, a short Swedish-Norwegian royal genealogy follows. In the chapter overview, which has a Latin heading, the individual chapters are marked with Roman numerals, which appear after the content of the respective chapters. This is followed by another Latin heading, which states that "The Booklet of Icelanders" now begins, before the ten chapters that tell the story of Iceland from the settlement to the first two Icelandic bishops. Throughout the narrative, great emphasis is placed on the establishment of institutions, such as the parliament and the judiciary, on the conversion of Iceland to Christianity, and on the institutionalization of the Church in Iceland. The closer the narrated time is to the time of the narrator, the more detailed his narrative becomes. This may also be due to the oral transmission that the narrator refers to as the origin of his knowledge of Iceland's history. The narrator then assesses the people who passed on their knowledge of Iceland's early history to him as very trustworthy and knowledgeable. In the first genealogy following this history of Iceland, the pattern of the previous narrative is taken up again, with a line of ancestors tracing the first two bishops of Iceland and the two bishops mentioned in the prologue back to the first settlers. The second genealogy then extends this pattern, since it describes the ancestral line of the narrator himself, starting from the mythical Yngvi, the progenitor of the Swedish Yngling lineage. The whole narrative of Íslendingabók, which in the manuscripts takes

3 'Its [Íslendingabók's] great age gives it inestimable value as a source of history, and it is no less precious as a literary monument, for it is the oldest example of narrative prose in a Scandinavian language” (Turville-Petre 1967: 90). "Íslendingabók ('Buch von den Isländern') ist der älteste bekannte erzählende Prosatext in einer skand[inavischen] Sprache [. . . ]” (Simek and Hermann Pálsson 2007: 208).

4 For an English translation of Íslendingabók, see Îslendingabók 2006 (3-14). 
up about twenty pages in folio format and is about fourteen pages long in print, is thus very dense in terms of content. The narrative thereby presents itself as a quasioral history transmitted in the form of a medieval, scholarly historiography that is not only intended to present the early history of Iceland but to inscribe Iceland as an independent entity in the world.

The prevailing opinion considers Íslendingabók to be a historical source that can be dated to the years between 1122 and 1133 (Jónas Kristjánsson 1997: 120-121) or, as Sveinbjörn Rafnsson argues, to the exact year of 1134 (Sveinbjörn Rafnsson 2001: 159). Such a dating of the text is mainly based on the assumption that the author-character mentioned in the narrative of Íslendingabók, known as Ari Porgilsson inn fróði, is the same person as the alleged medieval author of Íslendingabók (Jónas Kristjánsson 1997: 120-123). Furthermore, and according to the prologue of the narrative called Heimskringla in modern editions, the same Ari Porgilsson is said to be both the first person ever to write in the Old Norse-Icelandic vernacular and the first Icelandic historian (Heimskringla 1911: 2-3). Ari Porgilsson inn fróði is also mentioned in the prologue to the four Grammatical Treatises in Codex Wormianus, AM 242 fol, on fol. $42 \mathrm{r},{ }^{5}$ where he is said to have created - together with Poroddr rúnameistari - an Old Norse alphabet on the basis of runes, which they opposed to the Latin script. ${ }^{6}$ At the beginning of the First Grammatical Treatise, however, on fol. $42 \mathrm{v}{ }^{7}$ the first-person narrator claims to have independently compiled an alphabet for the Icelanders, which was composed both of Latin characters and of other characters that he found useful. This statement follows directly after a passage of text in which the narrator refers to books in which Ari wrote down historical knowledge in an understandable way. Since both the books attributed to Ari and the script system used in them remain completely unspecified, it is not possible to infer from the passage what narratives are to be found in them and in which language they were written. However, it can be stated at this point that on the basis of current knowledge, there are no actual medieval autographs associated with Ari porgilsson or medieval manuscripts known to contain a text called Íslendingabók. ${ }^{8}$ Having said this, someone called Ari prestr inn fróði is also mentioned as part of the rubricated incipit on fol. 1v in Fríssbók (Codex Frisianus, AM 45 fol), dated to the first quarter of the fourteenth century. ${ }^{9}$ The beginning of the incipit reads: Her

\footnotetext{
5 For a digitized version of Codex Wormianus and the relevant folio, see https://myndir.handrit.is/ file/Handrit.is/AM\%20242\%20fol./83/HIGH_QUALITY_DISPLAY (1 October 2020).

6 For an insightful discussion of the prologue, see Johansson (1997: 43-46).

7 For a digitized version of the relevant folio, see https://myndir.handrit.is/file/Handrit.is/AM\% 20242\%20fol./84/HIGH_QUALITY_DISPLAY (1 October 2020).

8 For the supposed influence of Ari on medieval Old Norse-Icelandic literature, see Turville-Petre's chapter on 'Ari and his influence' (Turville-Petre 1967: 88-108).

9 I would like to thank Prof. Dr Lena Rohrbach (University of Basel and University of Zurich) for drawing my attention to AM 45 fol. For a digitized version of the manuscript and the relevant folio,
} 
hefr vpp kon[vn]ga bok / ept[ir] savgn ara prestz froða [. . .] 'Here begins the kings' book, after the account of Prester Ari the Wise'. This rubric is not only remarkable due to the fact that it is an actual instance where a character named Ari prestr inn fróði is directly associated with an account or a narrative in a medieval manuscript, ${ }^{10}$ but also because the character mentioned in the rubric is associated with Heimskringa - named after the first two words of the continuous text also to be found on fol. $1 \mathrm{v}$ in AM 45 fol: KRINGLA heimsins - which is commonly attributed to the name and authorship of Snorri Sturluson today (Heimskringla 2016: vii-ix). ${ }^{11}$ Furthermore, there is a reference to Ari as the co-author of an earlier version of what later becomes known as Landnámabók, ${ }^{12}$ The Book of Settlements, a narrative describing the settlement of Iceland in the ninth and tenth centuries (Landnámabók 1968: 395-396). However, the text passage mentioned presents a problem of transmission, since it only occurs in the Hauksbók redaction of Landnámabók. The Landnámabók part of the medieval Hauksbók, AM 371 4to (Landnámabók: 155-184), written at the beginning of the fourteenth century is very fragmentary today and does not provide the epilogue containing the reference to Ari. This reference to Ari as the co-author of an earlier version of Landnámabók can be found in the manuscript AM 105 fol, ${ }^{13}$ written by Jón Erlendsson, dated to the mid-seventeenth century, which is assumed to be a copy of the not yet heavily fragmented Hauksbók, and in a text known as Skarðsárbók, a compilation produced before 1633 by Björn Jónsson á Skarðsá using both the Hauksbók and the Sturlubók redactions (Skarðsárbók: vii-ix), but Björn's autograph no longer exists either. ${ }^{14}$

see https://myndir.handrit.is/file/Handrit.is/AM\%2045\%20fol./2/HIGH_QUALITY_DISPLAY (1 October 2020).

10 A character called Ari Porgilsson inn fróði is also mentioned several times in Flateyjarbók (Gks $1005 \mathrm{fol}$ ), where the name mainly serves as confirmation for the accuracy of cultural memory or of the story told in the narrative. For an overview of these denominations, see the index of personal names in Flateyjarbók (1860-1868: 3:587).

11 The earliest reference to Snorri Sturluson as being the alleged compiler or even author of Heimskringla can be found in AM 93 fol, a Danish or Norwegian manuscript dated to 1540-1569: https://handrit.is/is/ manuscript/view/en/AM02-0093 (1 October 2020).

12 For a thorough discussion of the hypothesis of Ari as the co-author of Landnámabók, see Landnámabók 1968 (cvi-cxx) and The Book of Settlements (1972: 4-6).

13 For a digitized version of the manuscript, see https://handrit.is/is/manuscript/view/is/AM020105 (1 October 2020).

14 There are several manuscripts containing the Skarðsárbók compilation or redaction of Landnámabók that are believed to derive from Björn's autograph, all of which contain the reference to Ari's co-authorship with Kolskeggr inn vitri. AM 104 fol, a manuscript written by Ásgeir Jónsson between 1690 and 1697, is said to be a direct copy of Björn's autograph, which was presumably lost in the Copenhagen fire of 1728 (Landnámabók: xxxvi-xxxviii; similarly, Sveinbjörn Rafnsson 1974: 34-36) and depicts the passage in question on fol. 98r. Interestingly, the following manuscripts, which contain the same passage on the co-authorship of Ari and Kolskeggr, are dated as older than AM 104 fol on handrit.is: AM 108 fol, fol. 39v, written between 1650-1699; AM 110 fol, fol. 22v, 
And, just as in the case of the text we call Íslendingabók today, which is analysed in detail below, there is also no material evidence from the Middle Ages for Landnámabók that could be attributed to a historical Ari Porgilsson or would prove his co-authorship. Today, the association of both narratives with Ari Porgilsson and his (co-)authorship only derive from manuscripts produced in Iceland in the seventeenth century.

There is also a reference to a text called Islendinga bok on fol. $45 \mathrm{v}$ in the manuscript Holm Perg 18 4to, ${ }^{15}$ which includes the narrative of Ólafs saga Tryggvasonar en mesta and dates to 1300-1325. However, this passage of the narrative, which refers to an intradiegetic version of Islendinga bok as a textual source, only states that all the Icelandic people were Christianized at the alpingi, the medieval general assembly of the Icelandic Commonwealth (Saga Óláfs Tryggvasonar: 127-128).

These examples clearly show that the narrative we know as Íslendingabók gains its authority and credibility as a historical source for the early history of Iceland not only due to the assumed age and originality of the text, but also (a) due to the fact, that - in contrast to the anonymously composed Íslendinga sögur, which cover roughly the same historical period of time - Íslendingabók is ascribed to an intratextually and intertextually well-known author-name, Ari Porgilsson inn fróði, and $(b)$ on the basis of a reference to an intradiegetically mentioned text of the same name known in the diegesis of an early fourteenth-century konungasaga manuscript. The arguments used by previous scholars thereby refer to different levels of textual and narratological relations. An intratextual relation "guarantees the immanent integrity of the text" (Plett 1991: 5), whereby the references created by semiotic, semantic, or discourse structures are only analysed in a single manifestation of a text. ${ }^{16}$ If, on the other hand, the analysis focuses on intertextual relationships, several different texts and the semiotic, semantic, or discourse structures made up by the textually and narratologically interlinked network of those texts are taken into account. ${ }^{17}$ In contrast to the textual level, the analysis of the diegesis - the world created and presented in a fictional story - is an entirely narratological one. Every object or character mentioned in the narration is part of the diegesis, and as such it exists only intradiegetically. ${ }^{18}$

It must be noted, however, that all these mentions of Ari Porgilsson inn fróði or of Íslendingabók occur in manuscripts produced at least one hundred years - sometimes even several hundred years - after the supposed writing of Íslendingabók in the

1650-1682; and AM 111 fol, fol. 18v, 1600-1677. For a very detailed description of all known manuscripts of Skarðsárbók and of their stemmatological relationship, see Skarðsárbók: ix-xxxiv.

15 For a digitized version of the manuscript and the relevant folio, see https://image.landsboka safn.is/source/Holm_Perg_18_4to/Holm._Perg._18_4to,_0045v_-_91-hq.pdf (1 October 2020).

16 For a discussion of various theories of intertextuality, see Obermaier (2004: 23-35).

17 See also Obermaier (2004: 11-23) and Plett (1991: 3-29).

18 Most contemporary narratological theories using diegesis as part of their nomenclature rest on Genette (1980). For a more accessible introduction to Genette's theory, see Puckett (2016: 223-289). 
first half of the twelfth century. Therefore, the examples described cannot be interpreted as contemporary historical sources, but at best as quasi-historical literary testimonies of cultural memory. Nevertheless, I think it is no exaggeration to say that Íslendingabók is accepted as a highly canonized text today, structuring the scholarly understanding of both the early history of Iceland and the beginning of Old NorseIcelandic literary production, as well as shaping the self-conception of modern-day Icelanders and their cultural memory. ${ }^{19}$

\section{Íslendingabók as a mythically veiled past}

As just described, one can say that what we call Íslendingabók today is treated by some scholars as an original text from the twelfth century, or even as the "leiðstjarna íslenskrar sagnaritunar” ('the guiding star of Icelandic saga writing/historiography'; Björn Sigfússon 1944: 9). Such an assessment of the text is based mainly on palaeographical and linguistic approaches, on the understanding of the story told in the text as being historical fact, on the intratextually and intertextually well-established author-character of Ari Porgilsson inn fróði, and on an early fourteenth-century textual reference. Other scholars, who have a more critical view of Íslendingabók, are concerned with the narratological function of the text and its significance as the Icelandic foundation myth, rather than with the actual age and historicity of Íslendingabók.

In recent years, scholars with a more theoretical focus have started to argue that medieval literature should not be understood in accordance with modern standards of categories such as fictional and factual or mythological and historical. Margaret Clunies Ross for example, argues convincingly in her two volumes of Prolonged Echoes (Clunies Ross 1994; 1998) that, basically, no medieval Old Norse-Icelandic text can be categorized as being either historical or mythological in the sense of the modern dichotomy. From her point of view, history and mythology are integral parts of both the literary production and the exegesis and reception of every Old Norse-Icelandic literary text, and thus also structure the understanding and memory of Old NorseIcelandic culture. Picking up on these fundamental assumptions, John Lindow published a much-noticed article in which he argued that the narrative structures of Íslendingabók resemble those otherwise known from Old Norse-Icelandic foundation myths (Lindow 1997: 454-464). Furthermore, Lindow specifies the mythological nature of Íslendingabók as being manifest in two respects. On the one hand, he identifies Íslendingabók as a myth in the anthropological sense, as a story about how

19 The fact that the contemporary online database on genealogical information about all the inhabitants of Iceland is called Íslendingabók, too, shows how vivid the idea remains of a book containing all the names and genealogical relations of the Icelandic people from the very beginnings to today. For more information about this modern version of Íslendingabók, see https://www.islen dingabok.is/english (1 October 2020). 
Iceland came into being, and shows how Iceland was inscribed into some sort of reality on the basis of a narrative (Lindow 1997: 454-455, 462). On the other hand, Lindow draws parallels between the narrative structure of Íslendingabók and of other literary forms of Old Norse-Icelandic creation myths known from the Prose Edda and the Poetic Edda (Lindow 1997: 455), to show "how Icelanders made sense of themselves, of their identity and their society, within the wider geographical and historical world in which they lived" (Lindow 1997: 463).

In her articles on "Spatial and Temporal Perspectives in Íslendingabók" (Hermann 2005) and on "Íslendingabók and History" (Hermann 2007), Pernille Hermann picks up on Lindow's and Clunies Ross's preliminary considerations, adding Jan Assmann's theoretical concept of cultural memory (Assmann 2008; 2011) to her approach. On the basis of Íslendingabók, Hermann distinguishes the concepts of past and of history which, according to her understanding, never correlate with each other (Hermann 2005: 82-84). Furthermore, Hermann states that Íslendingabók, by means of its typological structure (Hermann 2007: 26-29), takes a formative share in the production of the cultural memory of a society, but is - at the same time - influenced by that society and its cultural memory (Hermann 2005: 84). Moreover, Hermann points to the fact that it is also the literary modes and discourses used in Íslendingabók that allow the text to be recognized and accepted as a foundation myth, turning Íslendingabók into one of the main actants in the creation of an Old Norse-Icelandic cultural memory (Hermann 2007: 19-22).

The above-mentioned positions continue to accept that the narrative in what we call Íslendingabók is somehow descended from the beginnings of Old Norse-Icelandic literary production in the twelfth century. Nevertheless, these approaches take an epistemological step forward insofar as they evaluate the narratological structure of Íslendingabók, describing it as being closely connected to the mythological mode of other Old Norse-Icelandic narratives, rather than accepting the narrative of Íslendingabók as a factual depiction of the history of the first centuries of Icelandic society.

\section{A short introduction to paratextuality}

My argumentation will build on these preliminary considerations by adding the theoretical approach of paratextuality - a term defined by the French literary theorist Gérard Genette (1997) - to analyse the modes of modification affecting Íslendingabók. According to Genette, a text - and this also applies to manuscripts - is rarely presented as a mere sequence of verbal statements but most often structured by additional information, which he labels as the paratext:

A literary work consists, entirely or essentially, of a text, defined (very minimally) as a more or less long sequence of verbal statements that are more or less endowed with significance. But this text is rarely presented in an unadorned state, unreinforced and unaccompanied by a 
certain number of verbal or other productions, such as an author's name, a title, a preface, illustrations. And although we do not always know whether these productions are to be regarded as belonging to the text, in any case they surround it and extend it, precisely in order to present it, in the usual sense of this verb but also in the strongest sense: to make present, to ensure the text's presence in the world.

(Genette 1997: 1)

According to Genette, such a paratext is a "threshold" between the inside and the outside of a text:

For us, accordingly, the paratext is what enables a text to become a book and to be offered as such to its readers and, more generally, to the public. More than a boundary or a sealed border, the paratext is, rather, a threshold, [. . . ] a 'vestibule' that offers the world at large the possibility of either stepping inside or turning back.

(Genette 1997: 1-2)

Paratexts structure both the textual layout of a manuscript or a book and its textual memory by referring to the narrative as well as to the world outside the text (see e.g. Rösli 2018). The narrative and its depicted or narrated diegesis, as well as the extradiegetic discourse associated with the narrative, are closely linked to the cultural and the scholarly memory of a given text and its literary value.

One of the best examples of a paratext that shapes our memory of a narrative is the title given to a text containing a particular narrative. ${ }^{20}$ The title enables us to refer - at least among speakers of the same language - to a certain text. The title thereby stands in place of the whole text or its narrative. It becomes a label, a pars pro toto for the whole text, without being, strictly speaking, a part of the text or narrative itself. I will therefore focus on the modification of titles in the following argumentation.

\section{Paratextual frameworks}

\section{The titles in the early manuscript transmission of Schedæ Ara Prests Fróda}

On the Monday after Dominica Jubilate - which is the Monday after the third Sunday after Easter - in the year 1651, the priest Jón Erlendsson finished a manuscript today known as AM 113 a fol, on behalf of Brynjólfur Sveinsson, the bishop of Skálholt (Már Jónsson 2012: 38). According to today's knowledge, this manuscript is the oldest manifestation of the text we commonly call Íslendingabók. Having said that, this is not what this text was titled in the year 1651. The title clearly reads Schedæ Ara Prests Fróða (Figure 1).

20 For an extensive study of the function of literary titles, see Rothe (1986). 


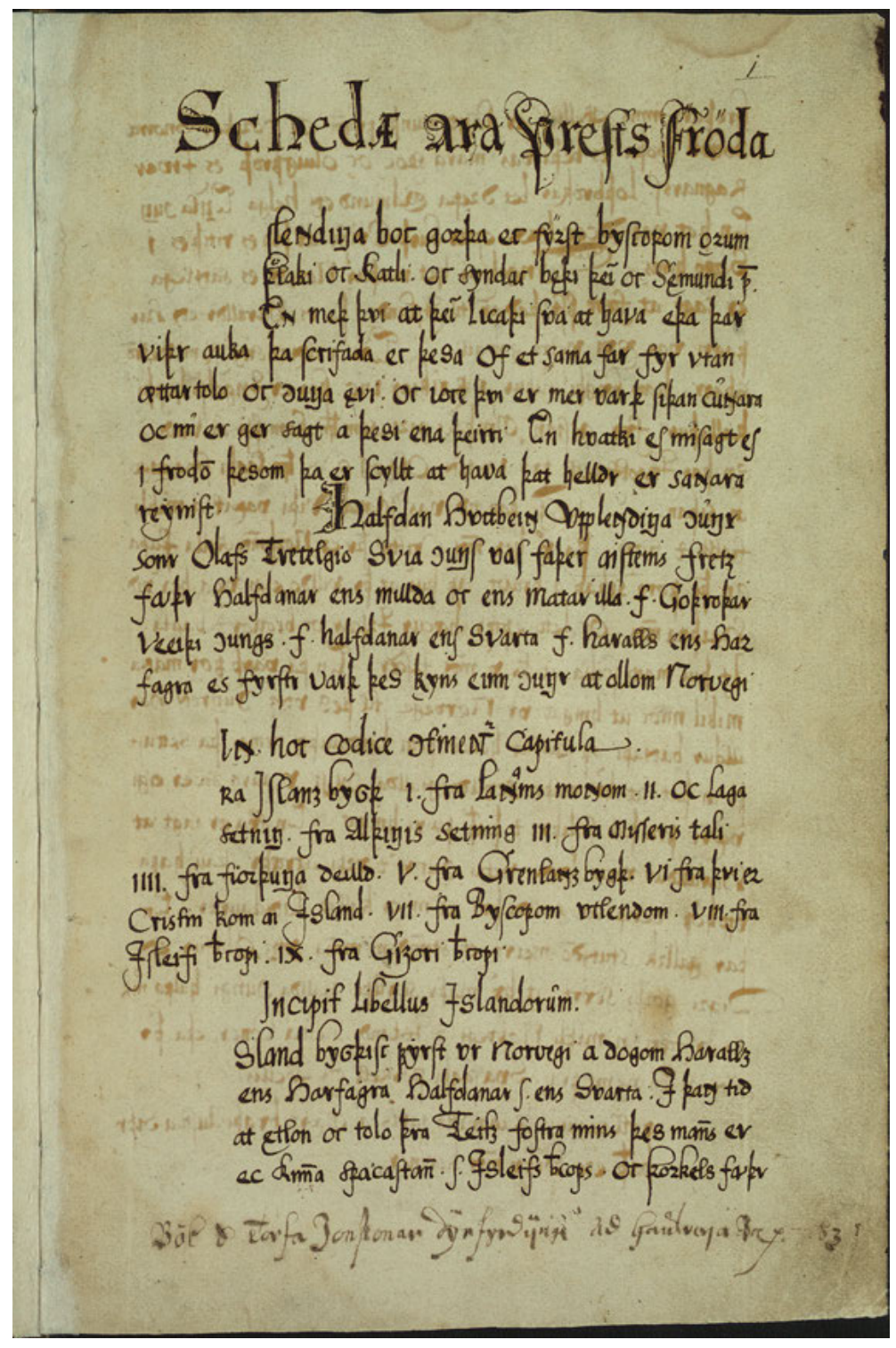

Figure 1: AM 113 a fol, fol. $1 r^{21}$

21 Unless otherwise noted, the copyrights for all images from manuscripts are owned by handrit.is. 
This title is a little tricky, as the ancient Greek word $\sigma \chi \varepsilon \dot{\delta} \eta \eta$ means 'papyrus leaf' and its Latinized version scheda can be translated as 'piece of paper'. According to Halldor Hermannsson, the term schedae - in its plural form and as used in seventeenth-century Iceland - refers to a collection of unbound or unsorted folios with some notes in it (The book of the Icelanders: 41-42), and could thus be translated as 'sheets'. If we take the title given to the oldest known manifestation of this text seriously, the word can be understood as a reference to a materially relatively "unstable text", ${ }^{22}$ rather than to a solidified text or narrative that is written down and irrevocably preserved in a book in the manner suggested by the title Íslendingabók. ${ }^{23}$ The concept of an unstable text based on an unsorted stack of folios to which the title refers as schedae is reinforced by the explicit (Figure 2) in AM 113 a fol.

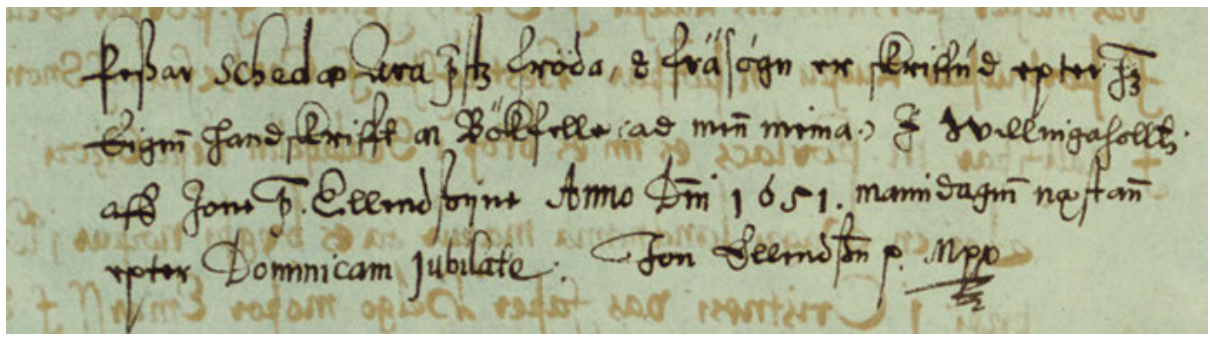

Figure 2: AM 113 a fol, fol. 7v (extract showing only the explicit).

In this explicit, Jón Erlendsson, the scribe of AM 113 a fol, again calls the text he has written Schedæ Ara Prests Fróða. This double labelling of the text as Schedæ Ara Prests Fróða - through the actual title at the very beginning and as part of the explicit at the end of the text - encloses the whole text. The whole narrative is thereby framed by the term schedae, highlighting the unstable idiosyncrasy of the text. This notion of textual instability is supported by yet another reference to an unreliability when Jón Erlendsson writes about the opinions other people had about the exemplar he copied: Pessar schedæ Ara prests fróða og frásögn er skrifuð eftir hans eiginhandskrift á bókfelli (að menn meina) i Villingaholti af Joni p. Ellendssyni Anno domini 1651, mánudaginn næstan eftir Dominicam jubilate. Jon Ellendsson p. mpp 'This Schedæ by Priest Ari the Wise and the story [in it] was written after his autograph on parchment (as people believe) at Villingaholt by Priest Jon Erlendsson, Anno Domini 1651, the next Monday

22 The concept of unfester Text was very fruitfully introduced to medieval German studies by Joachim Bumke to describe the nature of premodern textuality, where we cannot assume that a certain version of a text is more authoritative than another, even if it is transmitted in an older manuscript or in an allegedly more carefully copied one (Bumke 1996: 118-129).

23 For an alternative position to this argument, see Mundal (2012, esp. 217-220), using the title Íslendingabók as proof of the concrete "writtenness" (2012: 217) of the text. 
after Dominica Jubilate [= the third Sunday after Easter]. Jon Ellendsson $p$. mpp. [= per manu propria, [signed] with one's own hand]' ${ }^{24}$ According to the explicit in AM 113 a fol (Figure 2), some people, at least, thought the exemplar to be an autograph on parchment written by Ari Porgilsson inn fróði. Such a statement in the explicit clearly expresses a recognizable doubt on the part of the scribe about the exemplar he copied from. Jón Erlendsson's concerns raised in the explicit cannot be rebutted on a material level today, as the supposed original has been missing ever since. There is a letter from Reverend Torfi Jónsson to the famous Pormóður Torfason dated to 8 August 1684 - and thus thirty-three years after the self-referential dating in the explicit of AM 113 a fol, which is the only part of that manuscript qualifying as factual and extradiegetic content, as it clearly refers to the scribe and the explicit is written in his own hand. ${ }^{25}$ In the letter, Torfi writes that a vellum was found around 1650 in the cathedral at Skálholt containing what was thought to be Íslendingabók (Már Jónsson 2012: 38). The manuscript supposedly found at Skálholt has since disappeared, and even such notorious collectors of manuscripts as Árni Magnússon found no trace of it (Már Jónsson 2012: 38).

Shortly after the first manuscript of Schedæ Ara Prests Fróða (AM 113 a fol), Jón Erlendsson produced a second one now called AM 113 b fol (Figure 3), which, according to Árni Magnússon, has a text of the same narrative that is written in a slightly older script and is thus better looking (Íslendingabók Ara Fróða: xvij-xix). The title given to this narrative is the exact same as in AM 113 a fol (Figure 1): Schedæ Ara Prests Fróða.

Furthermore, as all the other manifestations of the text, which now bear the shelfmarks AM $113 \mathrm{c}-\mathrm{k}$ fol (Figure 4) and were all produced in the second half of the seventeenth century, are derived from the two aforementioned manuscripts written by Jón Erlendsson, the title Schedæ Ara Prests Fróða appears on the first folio of every instance of this text.

As a result, it seems safe to say, that - at least where the seventeenth-century paper manuscripts now bearing the shelfmark AM 113 fol are concerned - no one regarded the transmitted text as being called Íslendingabók; Schedæ Ara Prests Fróða was obviously the title ascribed to the narrative in question.

24 Unless otherwise noted, all transcriptions and translations are my own.

25 Cf. Margrét Eggertsdóttir (2010) or Helgi Tvarsson (2007). 


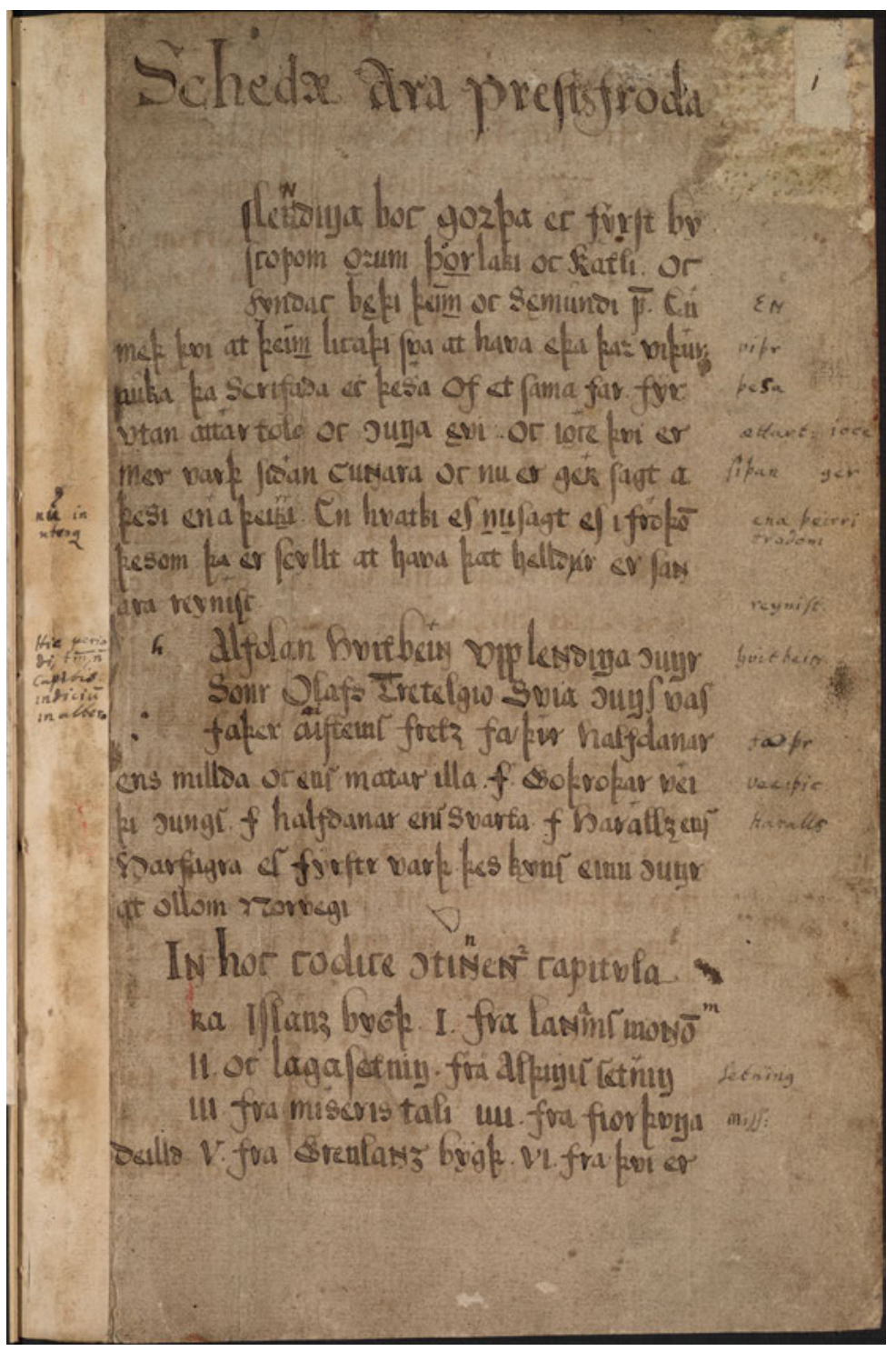

Figure 3: AM $113 \mathrm{~b}$ fol, fol. 1r. 


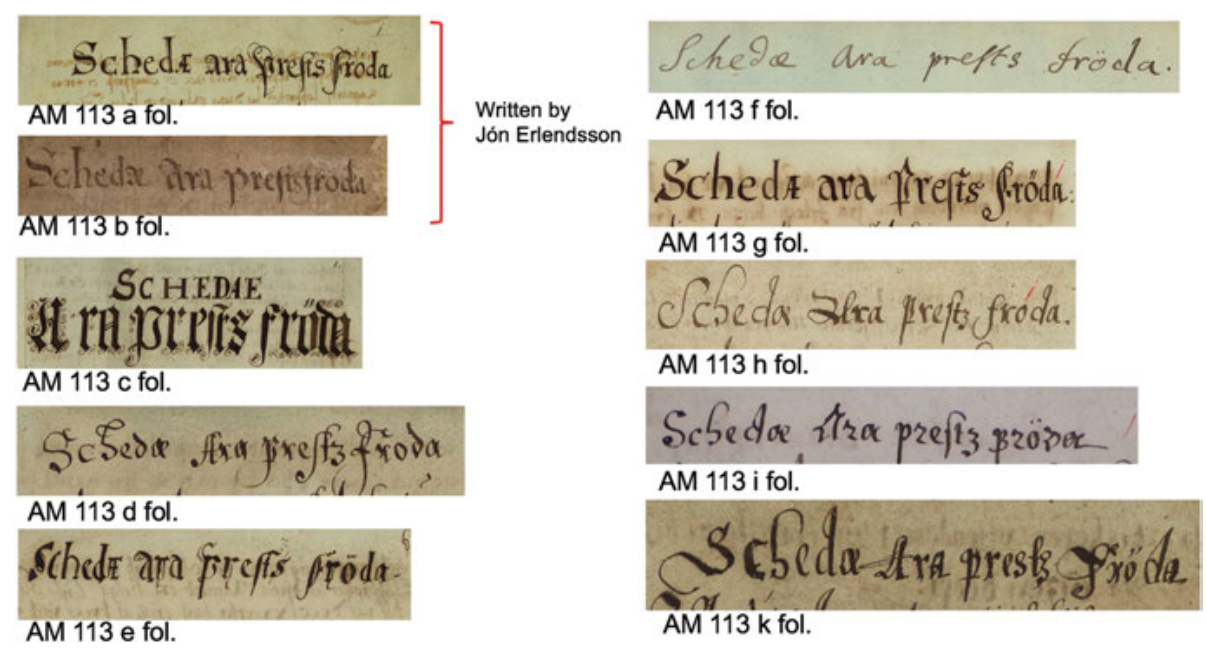

Figure 4: AM $113 a-k$ fol (extracts showing only the titles in each manuscript).

\section{The names of the text in Schedæ Ara Prests Fróða}

A closer look at fol. 1r of AM 113 a fol (Figure 5) reveals that three different texts are mentioned on this very first page:

At the top, there is the already-discussed title that calls the whole text Schedæ Ara Prests Fróða. The second reference to a text is to be found in the first two words of the continuous text, reading [I]slendinga boc, with the initial $I$ of the word Islendinga left out. Another reference, to a third text, is to be found just after the short table of content. Thereby, the Latin phrase Incipit Libellus Islandorum states a new beginning of the text. These are references to three different texts with different lengths and different ontological statuses. The title Schedæ Ara Prests Fróða provides the framework for the whole text, which in AM 113 a fol includes the title and the explicit. The first two words of the continuous text, [I]slendinga boc, are uttered by a personified narrator as part of the diegesis of Schedæ Ara Prests Fróða. This intradiegetic first-person narrator tells that he once made a text called [I]slendinga boc (gorpa ec). This same narrator tells that the text he calls [I]slendinga boc was an initial version that he later changed. It is not before the very end of the continuous text, and before the explicit closes the frame of Schedæ Ara Prests Fróða, that this narrator reveals his identity (Figure 6) by calling himself Ari: enn ec heiter Are 'and I am called Ari'.

The third part of the text starts just after the table of content, which appears to be influenced by early modern printing practices as well as by the typographical layout of books. This part of the text, which corresponds to the intradiegetic story or the main narrative, has the title Libellus Islandorum (The Booklet of Icelanders). This section of the text is probably thought to include the table of content, even though the 


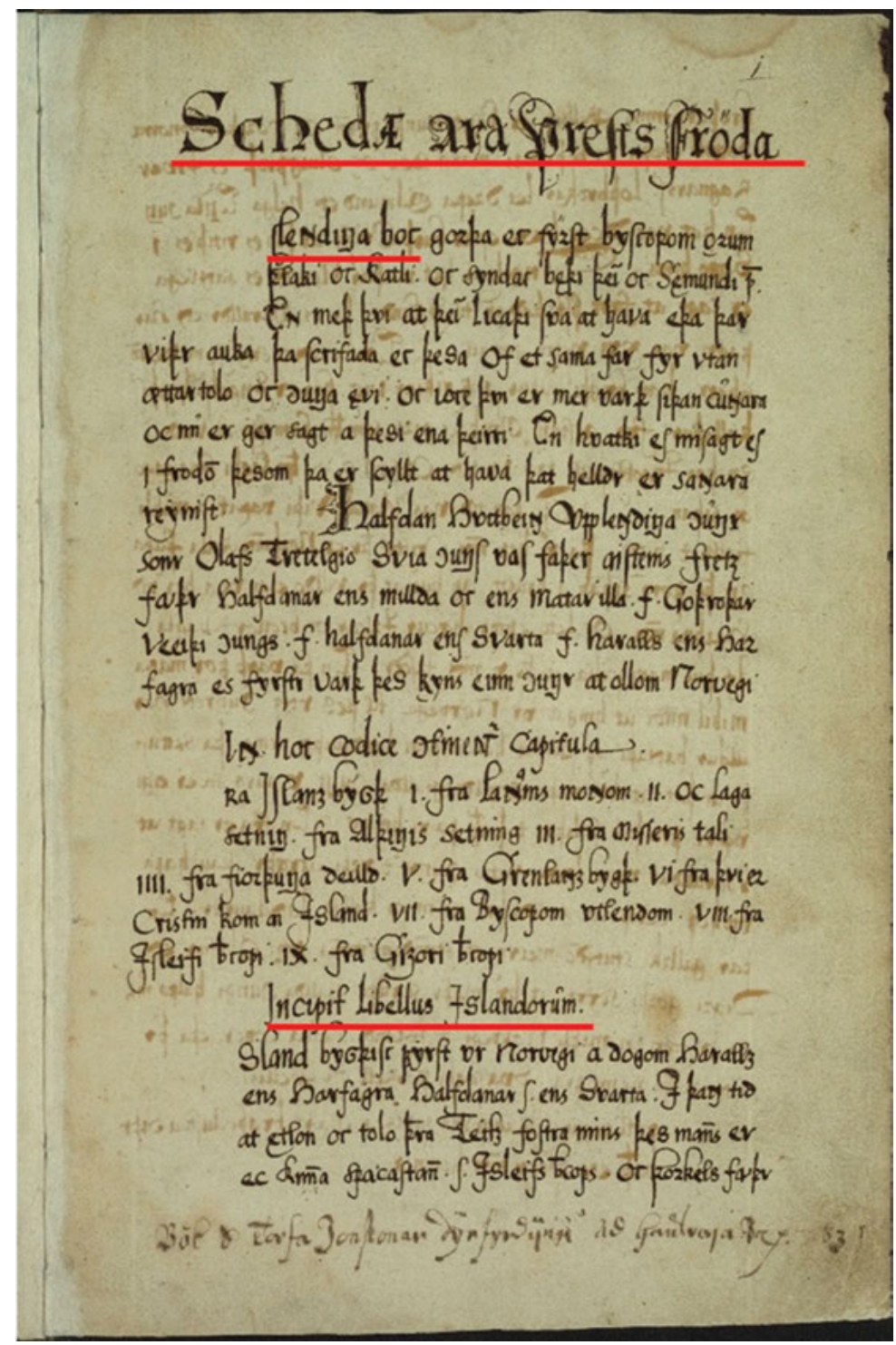

Figure 5: AM 113 a fol, fol. 1r (highlighting added).

actual intradiegetic narrative starts after it. It is evident, however, that Libellus Islandorum ends on fol. 6v (Figure 7) with the words Her lycr sia bóc 'Here ends this book'.

In AM 113 a fol, we have at least two frames for the body text, which is called Libellus Islandorum. The first framing of the body text and narrative starts with the diegesis presented by the intradiegetic narrator (who refers to an [I]slendinga boc, which he made previously but which is not presented, only referred to and 


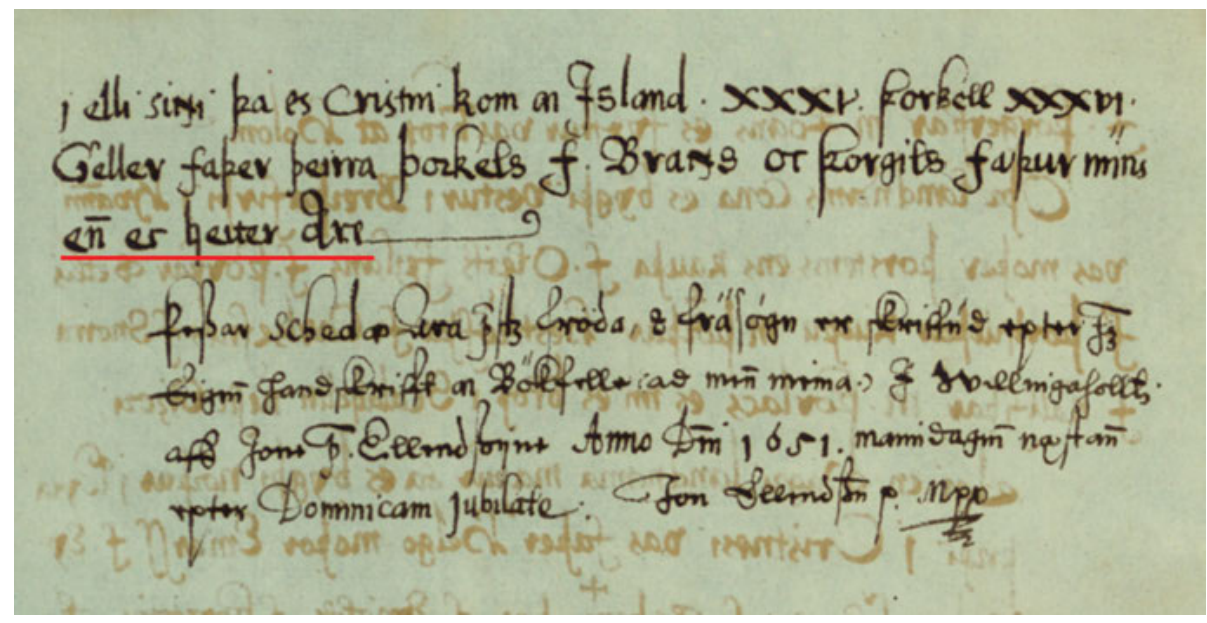

Figure 6: AM 113 a fol, fol. 7v (extract showing only the end of the continuous text and the explicit; highlighting added to show the self-referential naming of the intradiegetic first-person narrator).

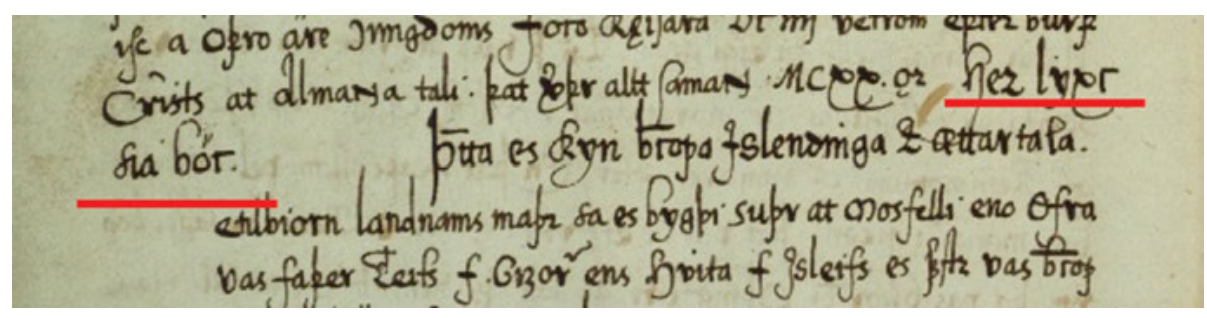

Figure 7: AM 113 a fol, fol. 6v (extract showing only the end of the intradiegetic story, or body text, and the beginning of the genealogy of the Icelandic bishops; highlighting added to mark the closing formula).

remembered, in Schedæ Ara Prests Fróða) and ends when this narrator states his name and calls himself Ari. The second framing is an extradiegetic one and present only in AM 113 a fol: an autograph by Jón Erlendsson, consisting of the title Schedæ Ara Prests Fróða (Figure 1) and the explicit (Figure 2).

The intradiegetic first-person narrator Ari Porgilsson has often been interpreted as being the historical author of the text Ari Porgilsson. However, the analysis of the narratological layers of the text presented in AM 113 a fol demonstrates that the intradiegetic first-person narrator Ari Porgilsson is a mere literary character in this narrative, and thus cannot be the same person as the extratextual author of the text or of the narrative. ${ }^{26}$

26 For an alternative position to a narratological argument, see Mundal (2012, esp. 216-217), which interprets the name of the narrator and the first-person narrating voice as proof of Ari's authorship. 


\section{The explicit of AM 113 a fol and its transmission}

From a strictly material philological point of view, the explicit in AM 113 a fol (Figure 2) is the only textual part rightly aspiring to an extradiegetic indication of the existence of a medieval exemplar, which was copied by Jón Erlendsson in 1651. Nevertheless, the reference to an autograph written by Ari Porgilsson, which is established and doubted at the same time in the explicit, creates only a memory of this medieval exemplar. As mentioned above, the main problem with this putative exemplar is that it vanished just after Jón Erlendsson produced the second copy, now known as AM 113 b fol (Figure 8).

It seems that Árni Magnússon realized how valuable the explicit in AM 113 a fol is with regard to the narrative's claim to authenticity, its authorization function for the whole narrative, and its creation of a cultural memory of the early history of Iceland. This is why Árni Magnússon himself copied the explicit from AM 113 a fol (Figure 2) into AM 113 b fol (Figure 9) when he got hold of Jón Erlendsson's second autograph.

Furthermore, Árni Magnússon considered this second manuscript produced by Jón Erlendsson to be a more exact copy of the ostensible medieval exemplar he never saw. He thus used B to denote AM 113 a fol and A to denote AM 113 b fol (Íslendingabók: xliv-xlix). This hierarchical assessment of AM $113 \mathrm{~b}$ fol was solely based on how archaic the scriptographical features of this paper manuscript seemed to him. In

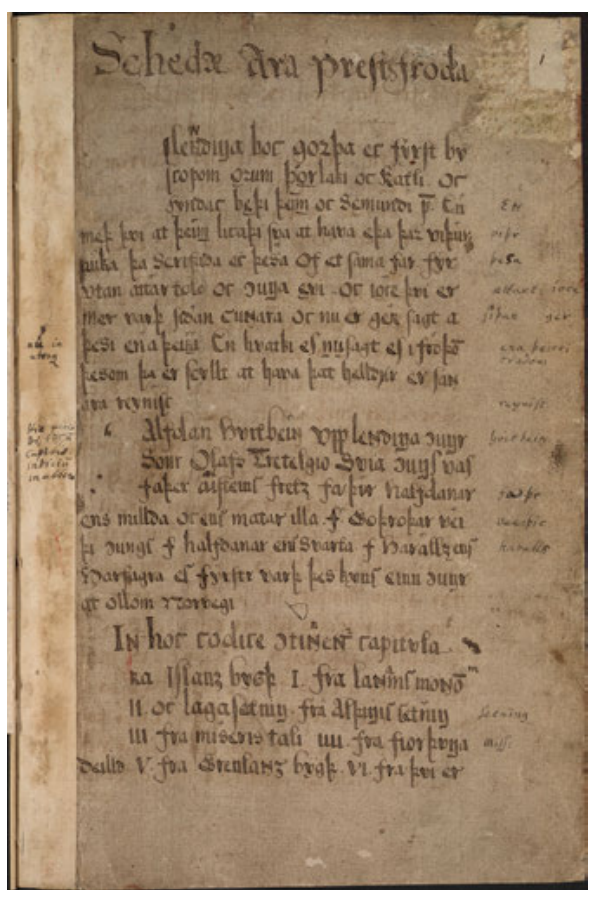

Figure 8: AM $113 \mathrm{~b}$ fol, fol. $1 \mathrm{r}$.

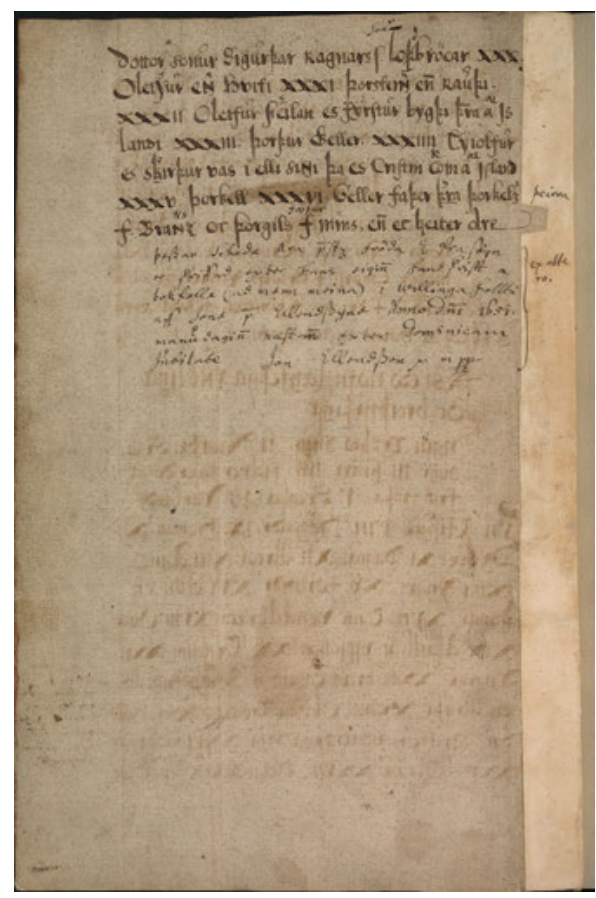

Figure 9: AM 113 b fol, fol. 10v. 
order to make AM $113 \mathrm{~b}$ fol into a valuable source with the same authority as AM 113 a fol, he had to add the explicit, which he therefore copied verbatim, including the per manu propria and Jón Erlendsson signature (Figure 10). This can be read as a scholarly or editorial mode of modifying both the actual artefact of the manuscript and the text that material artefact contains. Árni Magnússon did not only hierarchically classify these two manuscripts on the basis of how old the texts looked to him; he deliberately modified the manuscript AM $113 \mathrm{~b}$ fol by altering the extent of the text. One can argue, of course, that this can be seen as following the medieval practice of glossing or of commenting in the margin. Nevertheless, Árni Magnússon tried to complete and thereby to edit the very text version he considered to be older, which created, with regards to the explicit, a memory performance in the absence of the actual scribe. At the same time, this subsequent transmission through copying, which is highlighted in the manuscript by the sentence ex altero in the margin (Figure 10), creates a reminiscence of the manuscript AM 113 a fol, unintentionally emphasizing the dependence on the creation of memory in the original explicit.

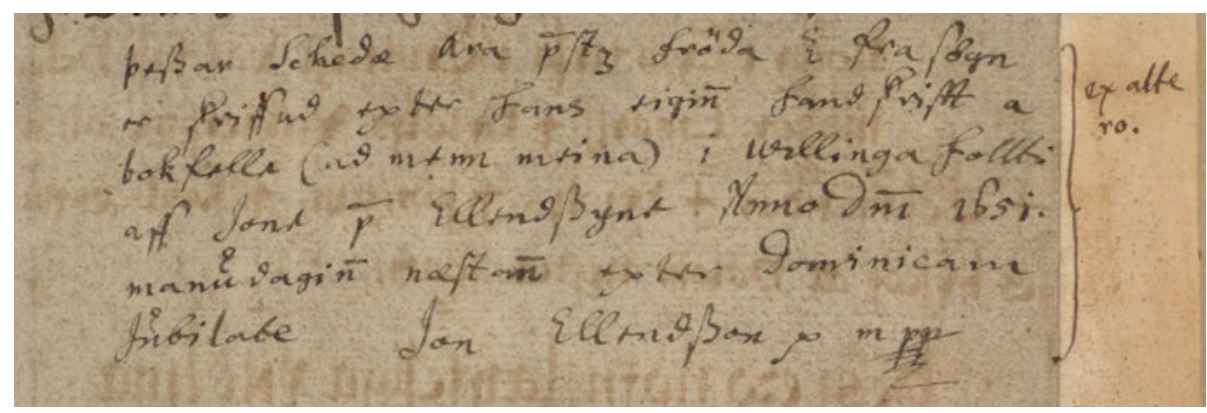

Figure 10: AM $113 \mathrm{~b}$ fol, fol. 10v (extract showing only the explicit).

In this context - and with regard to the title Schedæ Ara Prests Fróða and the explicit, which formed the main frame for the narrative and its diegesis in AM 113 a fol - it is interesting to note that we are not dealing merely with the textual medium of the manuscript. Title and explicit also found their way into early printed versions of the text.

The first printed edition was produced by the printing shop at Skálholt and published by Bishop Pórður Porláksson in 1688, just thirty-seven years after Jón Erlendsson had produced the first manuscript containing Schedæ Ara Prests Fróða (Figure 12). In contrast to the manuscripts discussed above, the title of the first printed edition includes a short addition, as the title now reads Schedæ Ara Prests Fróða Um Island (Figure 11). Thereby, the text itself (and not only the narrative presented in the text) becomes - for the first time in its history - explicitly marked with a quasi-national impetus, through a direct combination of the schedae with Iceland in the title of the printed book. 


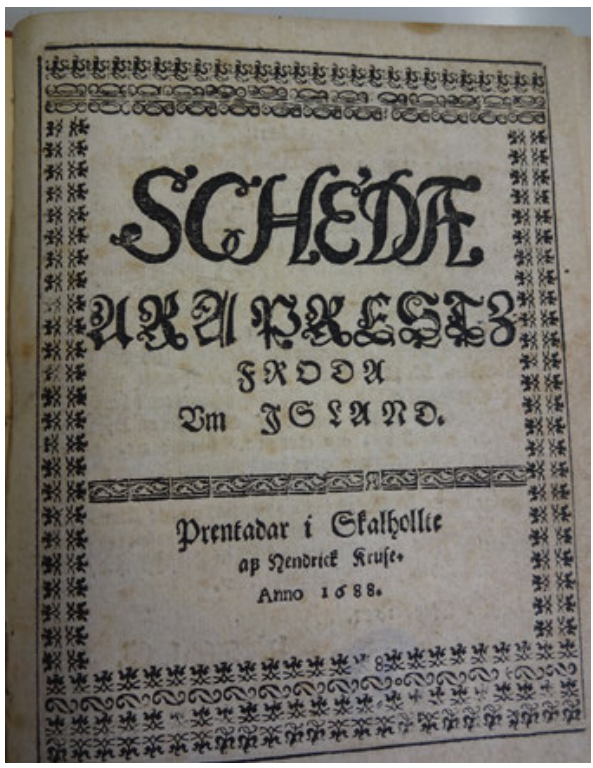

Figure 11: First printed edition, Schedæ Ara Prests Fróda Um Island, Skálholt, 1688, title page. ${ }^{27}$

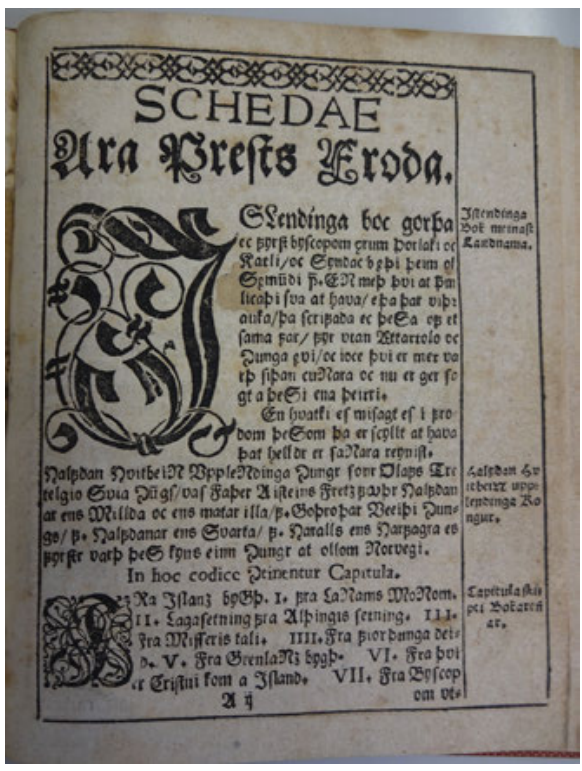

Figure 12: Schedæ Ara Prests Fróda Um Island, p. 1.

On the bottom of page 14 (Figure 13), the explicit - originally and uniquely written by Jón Erlendsson as part of AM 113 a fol - is once again depicted, as AM 113 a fol was used as the setting copy for this first printed version of Schedæ Ara Prests Fróða.

The last part of the text in the first printed edition from 1688 is still identifiable as a paratext due to the different size of the typeface (Figure 14). What was once an actual explicit in AM 113 a fol establishing the memory of when and where the manuscript was finished by Jón Erlendsson, and stating what people thought about the exemplar he used, becomes modified in the printed version, however. It is no longer the starting point of a memory that implies the existence of a supposedly medieval manuscript that was used as the exemplar. In its printed version, the explicit evoked the memory of a memory. The per manu propria abbreviation and the original signature seem to be totally out of place here, as it is materially evident that they are clearly not written by someone's own hand but printed with block letters. However, what once served as an explicit in AM 113 a fol did survive the medial modification from manuscript to printed book. This again shows that not only the manuscript, but in this instance the whole text of Schedæ Ara Prests Fróða and the creation of cultural memory that goes along with its narrative, are authorized and historicized through this paratext at the end of

27 The photos of the first print were taken by the author. 


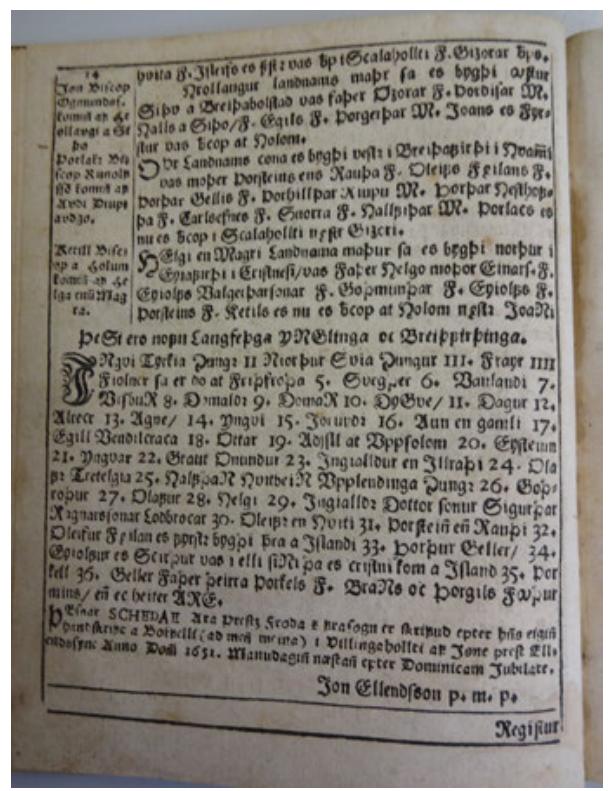

Figure 13: Schedæ Ara Prests Fróda Um Island, p. 14.

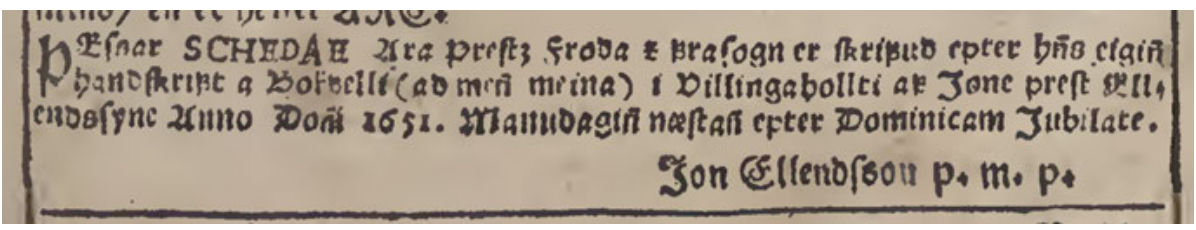

Figure 14: Schedæ Ara Prests Fróða Um Island, p. 14 (extract showing only the explicit).

the body text. The explicit, which is - both in its content and style - clearly linked to a hand-written manuscript, is used in this first printed version of the narrative to reaffirm the creation of cultural memory with regards to the foundation myth and the supposed transmission of Schedæ Ara Prests Fróða. In the case of the first printed version, the text passage depicting the explicit can no longer claim to be a reference to extradiegetic or even factual information, because the whole frame became a part of the main narrative when the paratexts of the printed version (such as the front page, the introduction, and the comments following the body text) singled out the body text Schedæ Ara Prests Fróða and its narrative to become an edited text, and thus became the central focus of the edition. 


\section{The equation of Íslendingabók and Landnámabók}

It might be argued that the publisher and the printer of the 1688 printed edition tried to recreate the manuscript AM 113 a fol as accurately as possible, just as we would expect a modern facsimile edition to do. But they altered too much in the actual text for such an argument to work.

Not only the initials at the beginning of chapters and paragraphs (Figure 15), which were not filled in throughout AM 113 a fol (Figure 1), but also marginalia (Figure 15), like glosses and comments, were added to the text of Schedæ Ara Prests Fróða. The addition of initials and marginalia makes the text less ambiguous, as it fills in - with regards to both the material and the content of the text the gaps that demanded some interpretative competence in AM 113 a fol. A very interesting clarification, which tries to explain the continuous text, can be found in the margin of page 1 of the first printed edition. The intradiegetic Íslendinga bóc is explained as Islendinga Bok meinast Landnama (Figure 15). Such an equation of Íslendingabók and Landnámabók, The Book of Settlements, might seem

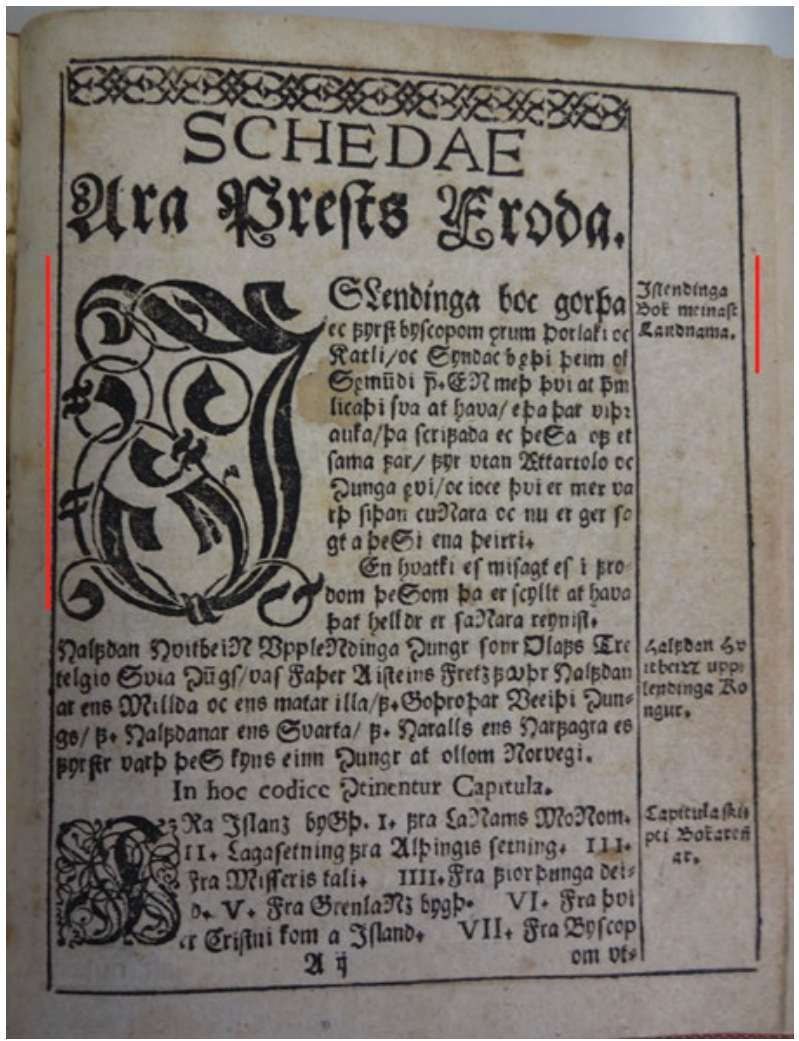

Figure 15: Schedæ Ara Prests Fróða Um Island, p. 1 (highlighting added). 
strange to modern readers, but it looks as if in the last quarter of the seventeenth century, the intradiegetic Íslendinga bóc was understood by recipients of Schedæ Ara Prests Fróða not as being the text and narrative of the schedae itself but as another text, not included in Schedæ Ara Prests Fróða. At least the publisher thought of the intradiegetic Íslendinga bóc as referring to Landnámabók, which becomes an intertext to Schedæ Ara Prests Fróða Um Island. An economically oriented explanation for the equation might be the fact that the first printed version of Landnámabók (Sagan Landnama) was separately published by Pórður porláksson at Skálholt alongside Schedæ Ara Prests Fróða Um Island. However, as Sagan Landnama is based on the Skarðsárbók redaction ${ }^{28}$ of Landnámabók (Landnámabók: xxxviii) discussed above, this first printed edition also contains the reference: $N U$ er farit yfer um landnam pav er verit ha=fa a Jslandi epter pvi sem froder men[n] skrifad ha=fa+ Fyist Are prestir hin[n] Fropi Porgilssun/ $z$ [ok] Kolskegor en[n] vitri [. . .] (Sagan Landnama: 173) 'Now the account of the settlements of Iceland is completed, according to what wise men have written, first Ari prestr inn fróði and Kolskeggr inn vitri'. The marginalium next to this section reads: Hvørier skri[f]ad hafi La[n]dnamo 'Those who have written Landnáma'. The intertextual reference of Schedæ Ara Prests Fróða Um Island to Sagan Landnama, which is established as discussed above (Figure 15), not only creates a simple connection between these two first printed editions of the two narratives but also establishes the merely intradiegetically mentioned Íslendinga bóc of the Schedæ as a synonym for the original version of Landnámabók. The authorship of both texts - of the original Landnámabók and of Íslendinga bóc, which is only mentioned in the Schedæ - is thereby confirmed and reinforced. Nonetheless, the problem remains that both intradiegetically mentioned texts, the Íslendinga bóc and the co-authored, presumably original version of Landnámabók, are not accessible, since they exist only within the diegesis that creates them.

All of these paratextual features and frames found in Schedæ Ara Prests Fróða Um Island are again to be found in the first edition containing a Latin translation, Aræ Multiscii Schedæ de Islandia, which was published by Christen Worm in Oxford in 1716 (Figure 16).

It is interesting to note that Worm inserted the word Prologus (Figure 17) after the Latinized title Aræ Multiscii Schedæ de Islandia on page 1 of the text. Thereby, Worm gives a new structure to the text, as not only the word Prologus becomes a new paratext to the body text, but, according to Genette's theory on paratextuality (Genette 1997: 161-293), the text part labelled and identified as prologue becomes perceptible in its entirety as a paratext. On the other hand, the intradiegetic title Libellus Islandorum is omitted in Worm's edition and translation. As a result, the text does not give

28 For a thorough discussion of which manuscripts were used to create Sagan Landnama, see Skarðsárbók (xxxiv-xxxvii). 


\section{ARA MULTISCII}

\author{
S C H E D $A$ \\ $\begin{array}{llllllllll}\mathcal{D} & E & I & S & L & A & N & D & I & A\end{array}$ \\ A C C E D I T \\ C O M M B N T A R I U $\mathrm{s}$, \\ Et Dissertatio de Are Multiscis \\ Vita $\&$ Scriptis. \\ OXONIA, \\ E THEATRO SELDONIANO. \\ An. Dom. M DCC XVI.
}

Figure 16: Schedæ de Islandia, front title page.

(1)

\section{Are Multiscin Schede D E ISLANDIA \\ PROLOCUS.}

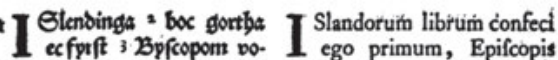
rum 4 Porlatt $\propto$ B Batli, $\propto$ ' finn- noftris Thorlako \& Ketillo, oac butbi tbeim $\propto$ Eemunoi \& videndum obtuli tam illis, - Prefti. IEnn meth thyi at quam Sxmundo Sacerdoti, tbeim 7 licatb $i$ fat at bava, cum vero illis hrec placuiffo etba that virbr aufa, tha fcri- viderem, \& poffe augeri vides fatha ec rbeffa of tc fama fat, rem, tum fcripfi hrecejufdem fir utan 9 Estartolo $\propto{ }^{10} \mathrm{Bun}-$ generis, prater genealogias, \& ga " avi, $\propto$ ioce thvi et mex Regum vitas, \& adjeci quare varth fitben cunnara, $\propto$ nu te mihi poftea notiora, \& nunc ger fegta theffi en a tbeiri. clarius dicta in his quam illis.

En buatti es mifagtes $i$ Quod vero eft erratum in "s frobum theffom/ tha $\boldsymbol{a r}$ hiftoris hifce, xquum eft has foilt at bavathat belor er fants bere illud potius quod vero nara reinift. propius.

Halfdanus

INTERPRETATIO.

Ut rem Epifcopis noftris Tborlako \& Ketillo gratam facerem, primo jam tum loco compofuerain libellum de inbabitatione IRandia, quem predictic Episcopis wti \& Samundo Sacerdoti videndum exbibui. Cum vero illis bunc placuiffe animadverterem, quem augeri poffe non ignorabam, bac ejufdem generis comfarip/h, prater genealogins of Regum vitas, eague adjeci, de quibus poftea fueram certior factus, \& proinde laculentius in boc quam iffo opere diela funt.

Inter illa vero, qua in bifce digla biftoriis, equifimam eris ea feligere, qua ad veritatem accedust propius.

$R \in x$

Figure 17: Schedæ de Islandia, p. 1.

any indication of where the Prologus ends. However, as Worm's edition presents a vast amount of commentary notes after every section of the text (Figure 18), which together with the Latin translation expand the paratextual apparatus of the whole text, one can argue that the Prologus ends with (and includes) the table of content, as the second section begins with a subheading reading Cap. 1 (Figure 19). Even though the title of the text in Worm's edition is translated into Latin and presented as Aræ Multiscii Schedæ de Islandia, it is still obvious that the text is remembered in the same way as it was in all the manuscripts and the first printed edition discussed above.

With the aid of a new paratextual element, the note number on page 1 (Figure 17) and its corresponding note on page 3 (Figure 20), Worm refers to Pórður Porláksson's reading of the intradiegetic Íslendinga bóc as being equivalent to the extradiegetic text known as Landnámabók, as found in the printed edition from 1688. The Latinized version of this equation solidifies the intertextual relationship between Schedæ Ara Prests Fróða Um Island and Landnámabók on an international level. Worm also took the explicit from AM 113 a fol, which was printed in the Skálholt edition as part of the intradiegetic narrative, and moved it into the preface to the commentary 
2

Halfdanus Huitbein Up- Balpoan 's Buitbein '4 Dps landorum Rex, filius Olxi tentoings sunger porr Olafe Tretelgie Sueciz Regis erat Eratelgtio is Evia tonungso bas

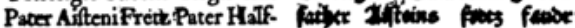

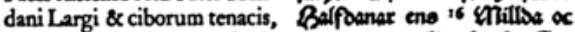
Pater Godrodi vethationis ets 7 h matik tha/ fautbe Bos Regis, Pater Halfdani Ni- throchar it Deithi Bango/ gri, Pater Haraldi Harfa- fautbe Balfounar ene pourta/ ger, qui primus erat ejus fautbe Baralls ano Barfas generis Rex totius Norve- gate co forfte varth thes gix.

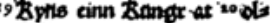
Iom Vtotrotgi.

IN TER PRETATTO.

Rex Uplandorum Haraldus cognominatus Albipes, qui Patriem babwerat Suecorum Regem Olaum, diffwm communiter Ligne riuim, fliwm babuit Aiftenum Pedorem, qui Pater orat Half. dani Largi quidem Jed is eduliis difhibuendisiniqui, Avus Go. drodi quem venationic anor oelebrem fecit, atevus Halfdasi Nigri Proaves Faraldi Pulcbricomi, qui ojus familie primics toti Norvegia imperavit.

In boc Codice continentur Mapkula.

De Iflandix inhabitatione. I fra J Jlanns onth.

De Illandix occupatoribus. II fra Katunaiths monmom. 2

De legum \& comitiorum con- fra Lagafaning $\propto$ 2lthinifis ftitutione.

De anni computo.

$$
\text { III fetning }
$$

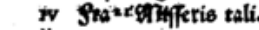

Deterra in quatuor partes di-

vifa.

fra fiotonga beillo.

De Gronlandix inhabiratione.

Stafrentants by 6

De tempose cum Chriftiani fra byi e Enifni foun a 3f5 venirent -Illandiam. wi tano.

De Epifcopis extraneis, vel fra bor fropom 21 utlendom. 8

De Ineifo Epifcopo ix fra 3fleifi Z3yfcopi. 9

De Giffuro.Epifcopo. $\quad x$ fra Gizoti 2 ypfopi. 10

Nota:

Figure 18: Schedæ de Islandia, p. 2.
6

\section{Ape Molriscit Schod \\ Of fabbe thar farris tinion/ \\ Et aluit ibi rapacem progeniem.}

Anglicum tamen à Grzco yiors derivat, Mer. Cefaub. p.285. 2s Ollom totius vel potius omnis Grettiefaga/ cap. 7t. lytr ollom obrum frum jefnaulorum/ fimilis ommibus fuis aqualibus, manifefta eft derivatio à Graco ïnes totus. Vide Qinofors cap. 18.

"1 GMifferi. Gitter Kolf/ B. i fuitbios mes mifilli gledi $\alpha$ fribit than mifferi/ Sedit Rolfo Rex in Suecia cnom magno gav. do per aligwot annos. Gautrifs fagts 26 .

21 Dilendom/ extraneis quafi extra eam terram nati, hinc Eurfi in Dlafäaga cap. 2. Hagwinem Sigurdi interrogat, bact $\alpha$ tbcefi bum bilendi mador/ quis eft ille extraneus vit \& clarius paulo poft. Iftnn that var lang $i$ landi tbui/at o

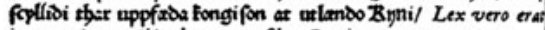
in es regione ne ibi educeretur filus Regis ex genere extranco.

\section{CA P. I.}

Sland ' Bepgrbift fyrft ur nat cons frurts/ $i$ than tith at flii Nigri, eo tempore, fecun. - Erton og tolo/; Peirra + Ecit3 dum opiniones \& fermones 'foftra mins tbefs mans er eorum: Titi nutricii mei, viec Barnas 6 Epacaftann fonar ri, quem ego nofco fapientif.

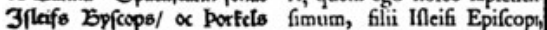
fanty brocturs mins geflis fos \& Thorchilli Patrui mei Gel. nar a langt 7 mundi fram $\propto$ leri filii, is longe meminit, \& Thoridz

$$
\text { INTERPRETATIO. }
$$

Tempore, quo regnavit in Norvegia filius Halfdani nigri Ho raldus Palcbricomus, fixere primo in Iflandia domicilia Nor. vegi prout fentiunt, mibigue fepius narraverumt, Filius 1feiff Epifcopi Titws, qui wana mecwm enutritus eff, of quem proinde fapientifjumm probe novi, or Tborkillws Gellieri filius Patruw

\section{DE ISLANDIRo}

Nota.

- Tflenbinga boc, addit Ebotlacius: meinaft Ranonama/ intelligitur Landnoma, liber confcriptus de originibus \& occupatione Iflandix.

2 Boc coincidit plane cum Gothico B\&K \& Saxonico boc, digniffima vifu funt, quie de hac voce babet Kæro.

Figure 20: Schedæ de Islandia, p. 3 (extract showing only some commentary notes).

section of the edited and translated text (Figure 21). Hence, one of the framing elements of the text and of the narrative, as presented by Jón Erlendsson in AM 113 a fol, is lost in this edition. The reason why Worm excluded the explicit from his edition might be due to the fact that the commentary section states that this explicit was part of the Skálholt edition. It thus seems likely that Worm did not know about Jón Erlendsson's manuscript at all, and that he therefore was not able to verify the value of the 


\section{(9r)}

I

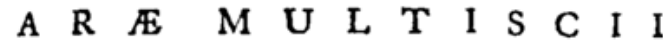 \\ Librum de Iflandia Commentarius.}

Commentarius in Prxfationem.

A Re Frode Schede de IJandia, quin titulus libro huic A ì recentiori manu fit additus dubitare me non patiuntur inta, qux poft editionem Scalaholtianam hebentur: $\mathbf{P}_{\boldsymbol{c}} \in$ far Grbeox 2lata Preftz froda oc frafogn ero fcrifuo epter bans cigin banofcrift à Bokfelli (ad men mcina) i Villinga hollti af Jone preft Elendflyne Anno Dom. 1651. Manudagin naftann epter Dominicam dubitate, cui \& affurgit Thorlacius, qui Schedas hafce Scalaholtix, ubi Epifcopus erat, edidit, is quippe ita: Bad gamla Manufcriptum fem $\mathfrak{b}$ yfcu=

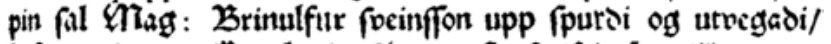

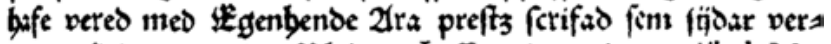
out nockud ungeted i bleoum Peffum / antiquum illud Ma-

Figure 21: Schedæ de Islandia, p. 91 (extract showing the preface to the commentary).

explicit. Nevertheless, Worm uses the explicit in the commentary section of his edition to reconfirm the Old Norse-Icelandic title attributed to the text and to the narrative, which he knows as Schedæ Ara Prests Fróða Um Island (Figure 21). In addition, Worm's printed version of the explicit emphasizes the statement about the presumed author and about the original by highlighting this passage using a special font. Those passages in the explicit that refer to the completion of Jón Erlendsson's actual writing process are, however, set in the same font as the rest of the commentary. This procedure of using an older-looking print type shows a clear historization of part of the explicit, which also manifests itself paratextually.

The third printed edition of the same text, which again includes a Latin translation, was published by Andreas Bussæus in Copenhagen in 1733.

Even though the front title page (Figure 22) of Bussæus' book includes the words Schedae, Libellus de Is-landia, and Islendinga-Bok, the bastard title page (Figure 23) and the first page of the actual text (Figure 24) refer to Schedæ Arii Polyhistoris De Islandia and Schedæ Ara Prests Fróða respectively. The equation of the three different designations established on the front title page is thus diminished or even contradicted on the following pages, as the body text is still referred to as Schedæ Ara Prests Froda, and is therefore labelled in the same way as in the manuscripts and the two printed editions discussed above. In contrast to Worm, Bussæus modifies the title's paratextual significance on page 2 by adding a footnote 


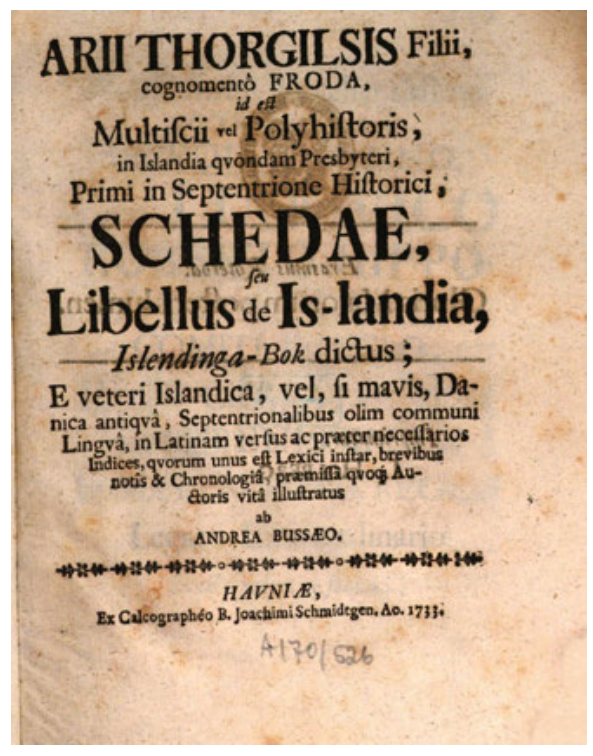

Figure 22: Schedae, seu Libellus de Is-landia, front title page.

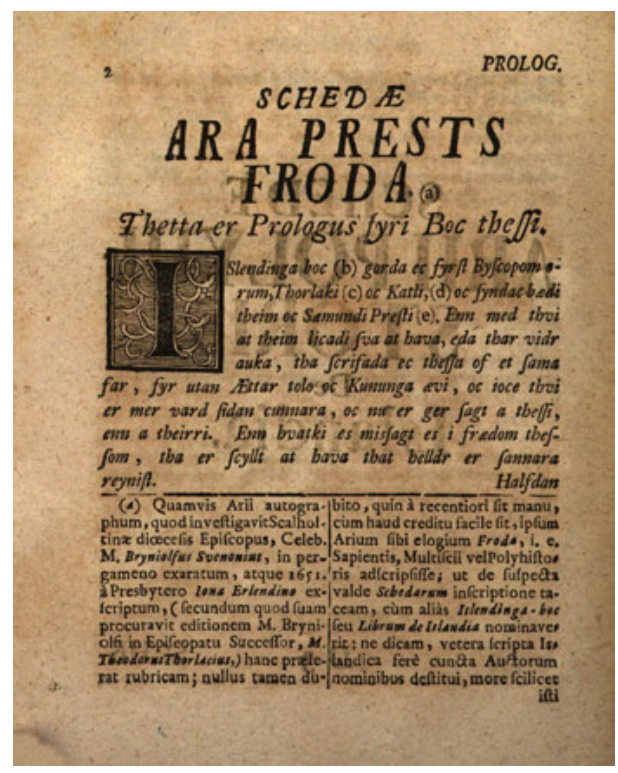

Figure 24: Schedae, seu Libellus de Is-landia, p. 2.

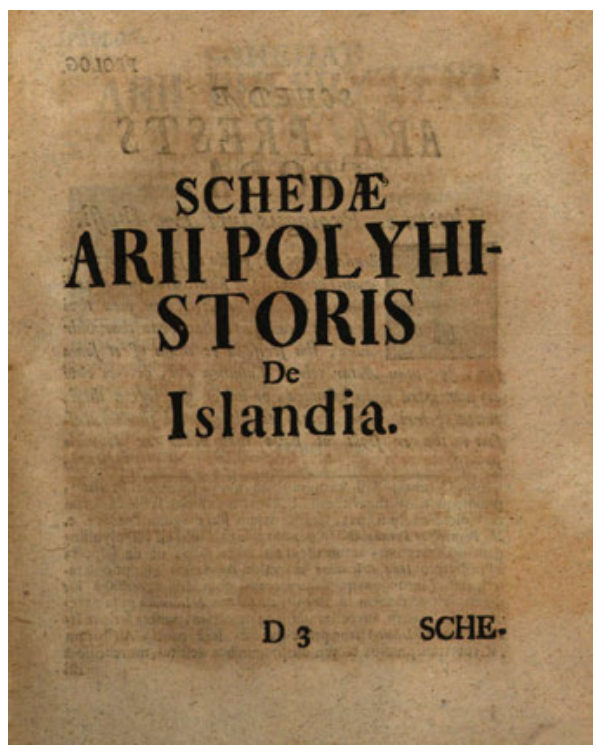

Figure 23: Schedae, seu Libellus de Is-landia, bastard title page. 
stating that Schedæ Ara Prests Froda is the title known from the manuscripts, but he somewhat doubts that this exact designation was already used in Ari's autograph. Moreover, the front title page labels Ari as being Primi in Septentrione Historici, the first Nordic historian. By doing so, the front title page establishes both a geographical and a temporal beginning, using Ari as the point of reference for the memory of Old Norse-Icelandic history and historiographical writing. Furthermore, Bussæus also modifies the part of the text which - at least since Worm's edition - is known as the Prologus, as he embeds the Latin Prologus in an Old Norse-Icelandic phrase: Thetta er Prologus fyri Boc thessi. This unmarked modification in the Old NorseIcelandic text thereby appears as if it was always a part of the original text written by Jón Erlendsson in AM 113 a fol or AM 113 b fol.

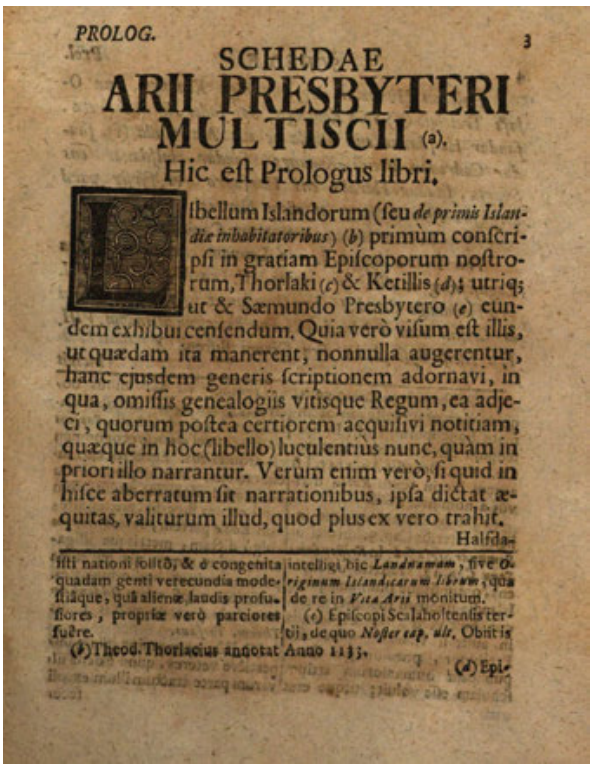

Figure 25: Schedae, seu Libellus de Is-landia, p. 3.

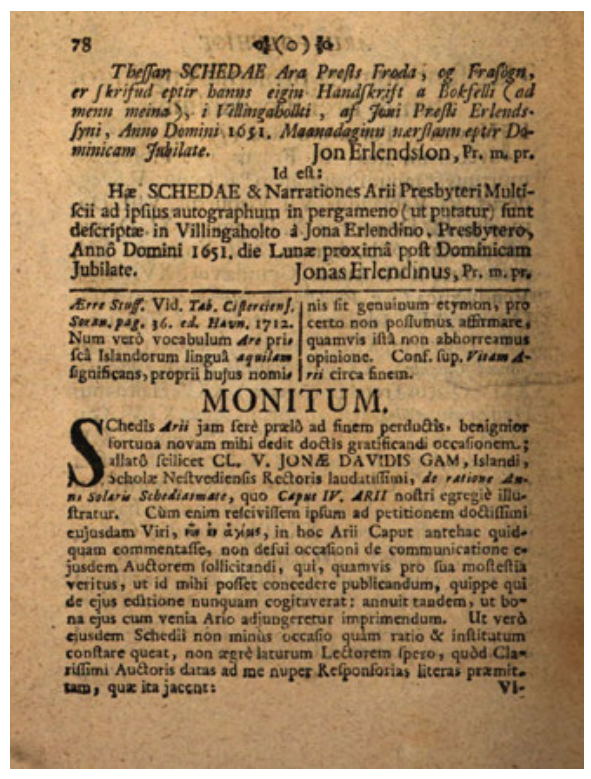

Figure 26: Schedae, seu Libellus de Is-landia, p. 78.

Bussæus' edition refers, just like Worm's did, to Pórður Porláksson's reading of the intradiegetic Islendinga boc as equivalent to Landnámabók (see footnote b, Figure 26), but this topic is already critically discussed in the prepended chapter on Ari's life (Schedae, seu Libellus de Is-landia, Islendinga-Bok dictus: without page numbers). In contrast to Worm's edition, Bussæus' publication includes the explicit written by Jón Erlendsson in AM 113 a fol, which is even translated into Latin in the edition, but it is not discussed or commented on in any way (Figure 26). Hence, the framing of Schedæ Ara Prests Froda generating the memory and perception of the assumed medieval exemplar remains intact, even though the text of the schedæ is modified tremendously 
by a vast amount of additional paratexts such as editorial and scholarly comments, a glossary, various prefaces, and instructions for the reception of the text.

\section{From Schedæ Ara Prests Fróða to Íslendingabók}

\section{The change of name}

The first written evidence of the intradiegetic text Islendinga boc becoming Íslendingabók, and as such the title for what once was known as Schedæ Ara Prests Fróða, can be found in one of Árni Magnússon's notebooks. Árni Magnússon always wanted to publish a scholarly edition of the text in question on the basis of all the AM 113 fol manuscripts he collected, using AM $113 \mathrm{~b}$ fol as the body text of the edition. It is probably no surprise to mention that Ârni Magnússon never managed to finish this project of a scholarly edition of the collected AM 113 fol manuscripts.

The notebook in question, consisting of three volumes today, bears the shelfmark AM 254 8vo. According to the description of the manuscript on handrit.is, Árni Magnússon wrote the notebook between 1700 and 1725.

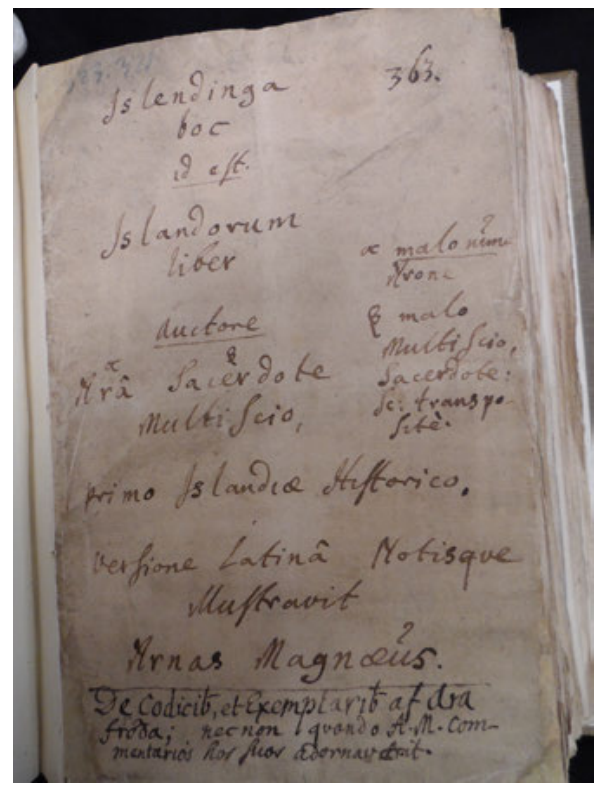

Figure 27: AM 254 8vo, fol. 1r. ${ }^{29}$

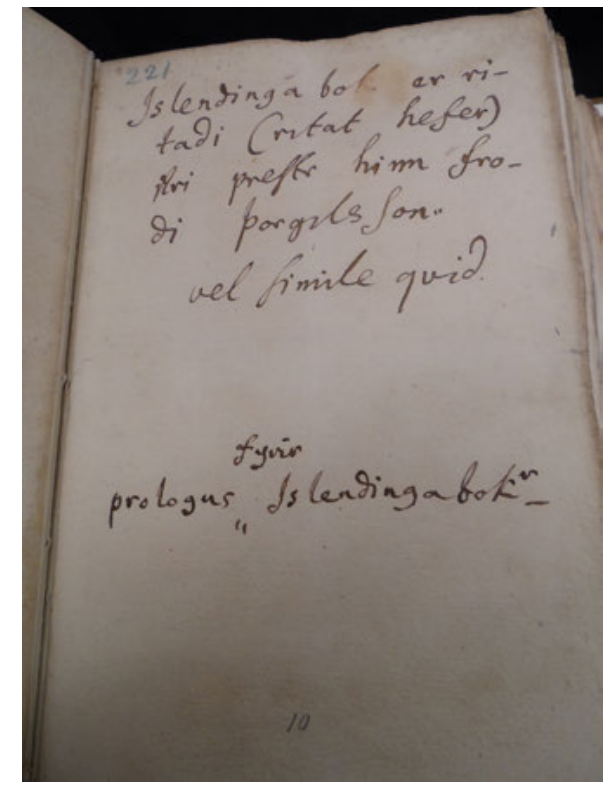

Figure 28: AM 254 8vo, fol. 10r.

29 All images of AM 254 8vo are my own. 
On fol. 1r of the first volume of AM 254 8vo, Árni Magnússon seems to modify the whole notion of the text, as he calls it Islendinga boc (Figure 27). Further down the page, which is structured like the front title page of a printed book, Árni Magnússon labels Ara Sacerdote Multiscio, which seems to be his Latin translation of Ari prestr inn fróði, as auctor, which refers to the editor or the author of a text. Furthermore, he calls Ari primo Islandiæ Historico, the first Icelandic historian. By doing so, Árni Magnússon establishes Ari as the point of reference for Old Norse-Icelandic historical memory, at least in the semi-private context of a notebook, several years or even decades earlier than discussed for Bussæus' edition, which, of course, had a far more public outreach.

On fol. 10r (Figure 28), Árni Magnússon states that Islendiga bok was written (er ritadi) by Ari vel simile quid 'probably in a similar way'. It is uncertain here if this assessment of the similarity of the written text refers to the intradiegetic Islendinga bok, which according to the narrating Ari in the diegesis was a first version, or if it refers to the actual text and narrative from the schedae. Either way, this statement tries to close the temporal and factual gap between the schedae from the middle of the seventeenth century and a supposed medieval text written by Ari. According to his own notes, Árni Magnússon considered it appropriate to change the title to Islendinga boc, although all manuscripts and printed editions gave Schedæ Ara Prests Fróða as the title, since he assumed that it was an invention of Jón Erlendsson, since

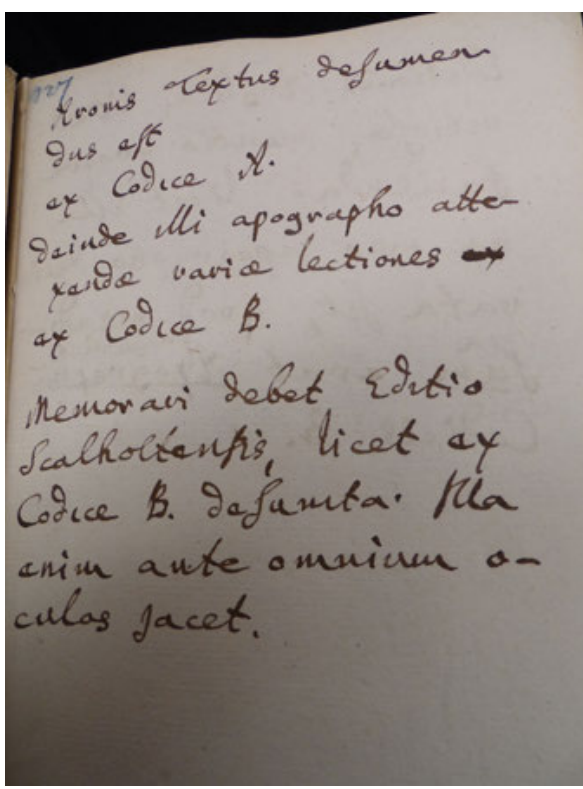

Figure 29: AM 254 8vo, fol. 25r.

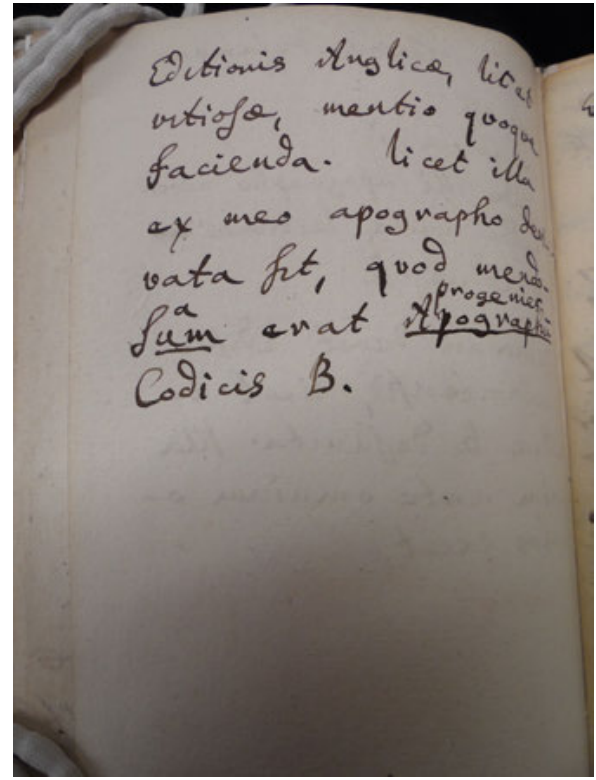

Figure 30: AM 254 8vo, fol. 25v. 
the text itself referred to an Islendinga boc, and since the incipit heading referred to Libellus Islandorum (Árni Magnússons Levned og Skrifter 2: 21). ${ }^{30}$

On fol. 25r (Figure 29), Árni Magnússon comments on the two manuscripts AM 113 a and b fol, which he calls Codice $A$ and Codice B, but Ârni's A is AM $113 \mathrm{~b}$ fol and his $\mathrm{B}$ is AM $113 \mathrm{a}$ fol, as he thought the later one (AM $113 \mathrm{~b}$ fol) presented a more archaic and thus a more original text, as mentioned before. On the same folio, Árni Magnússon also comments on the Skálholt edition from 1688, which he correctly identifies as being based on AM 113 a fol, and on fol. 25v (Figure 30) he comments on what he calls Editione Anglicæ (the English edition), which is Christen Worm's edition published in Oxford in 1716. He criticizes both editions for making use of AM 113 a fol instead of AM $113 \mathrm{~b}$ fol, which he thought to be closer to the archetype of the text. On the basis of these statements, one can see Árni Magnússon's argumentation, and his evaluation of manuscripts and their reliance on an autographical original or on a hypothetical archetype, as an anticipation of Lachmann's textual criticism.

In 1755, the scribe Jón Ólafsson úr Grunnavík, together with Bernhard Møllmann and Jón Sigurðsson, produced a manuscript today known as AM 411 fol. It is a posthumous attempt to create at least a manuscript version of Árni Magnússon's intended edition of what he called Islendinga boc.

In accordance with Árni Magnússon's notebook, the front title page of this manuscript (Figure 31) states that Ari Porgilsson was the first Icelandic historian, and the text now called Libellus de Islandia is directly attributed to Ari in this function of mediating the early history of Iceland. Furthermore, the title page states that Libellus de Islandia was written almost six hundred years earlier in the Icelandic vernacular. This, of course, evokes the assumption that the narrative presented in this manuscript is a direct account of the early history of Iceland written down in the eleventh century. The fact that the narrative was originally mediated through a seventeenthcentury manuscript written by Jón Erlendsson is, at least on the front title page, totally omitted. The starting point of the memory of the early history of Iceland, or rather of the narrated past as presented in AM 113 a fol on the basis of a supposed medieval manuscript, is thereby ignored. By mentioning Árni Magnússon as translator of the text, the front title page, on the other hand, builds a bridge between the eleventh century and the most recent past, elevating Árni Magnússon to the source of the Latin version of the memory created in the translation.

At the top of page 4 (Figure 32), which is the beginning of the Old Norse-Icelandic text in AM 411 fol, the scribe states that he copied the text from the Skálholt edition of 1688 to produce this manuscript. The fact that AM 113 a fol was used to produce this edition in memory of Árni Magnússon is not without a dash of irony, as it represents the exact manuscript Árni Magnússon thought to be a less good copy of the unknown exemplar, and which he thus called $B$. As Jón Ólafsson copied the text from the

30 I would like to thank one of the two anonymous peer reviewers for pointing this out to me. 


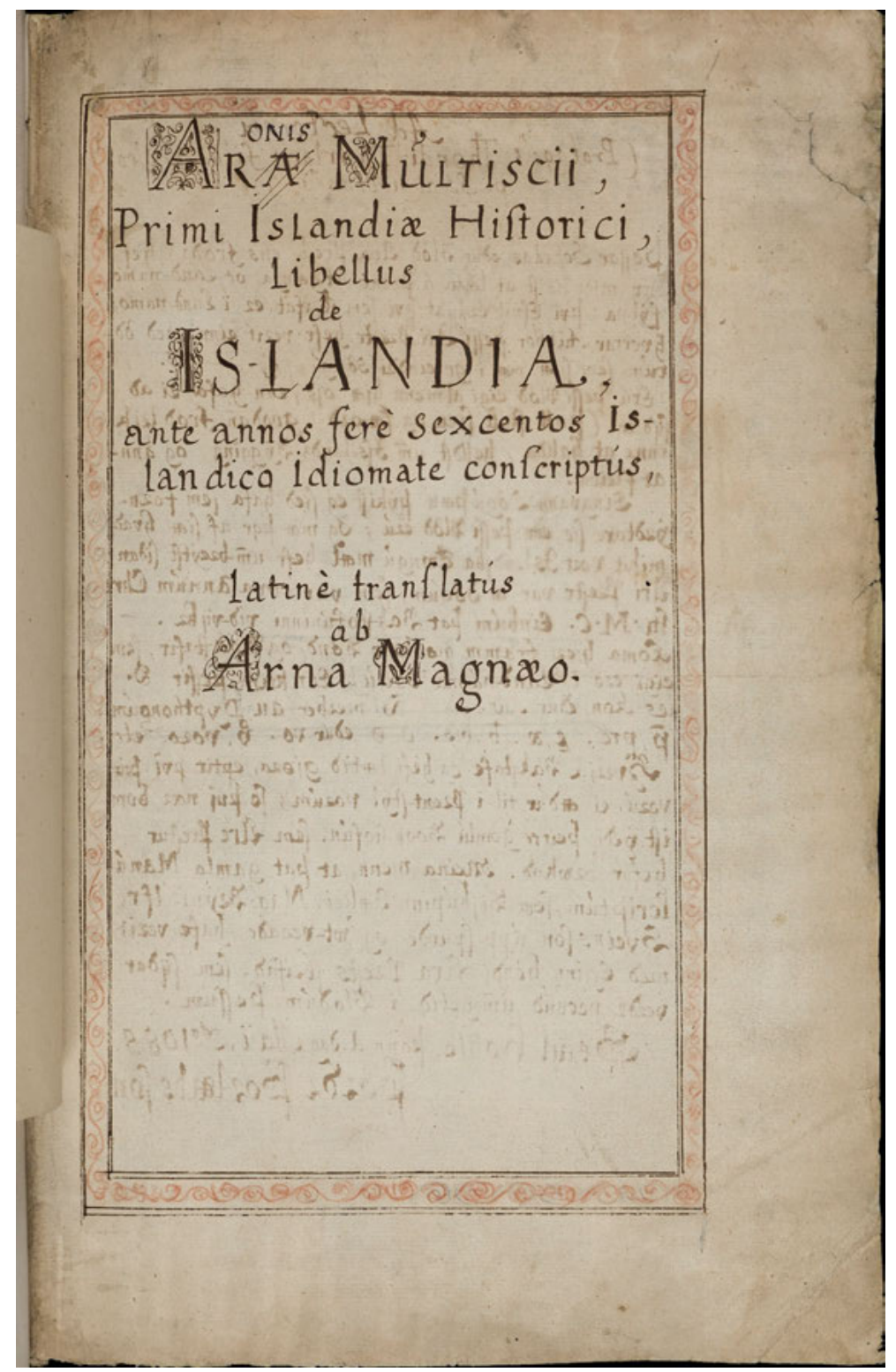

Figure 31: AM 411 fol, front title page. ${ }^{31}$

31 I would like to take this opportunity to thank Sigurður Stefán Jónsson who, at my request, professionally photographed the manuscript AM 411 fol. The copyright to the images is owned by Stofnun Ârna Magnússonar í íslenskum fræðum. 
Skálholt edition, the Old Norse-Icelandic title reads Schedae Ara Prests Fróða. On page 5 (Figure 33), the facing Latin text following Árni Magnússon's translation does not provide a proper title but instead introduces the following text as being the Prologus. Consequently, the Latin version of the whole text or narrative anticipates its title with the front title page. Libellus de Islandia has thus to be interpreted as the Latin equivalent of the Old Norse-Icelandic Schedae Ara Prests Fróða.

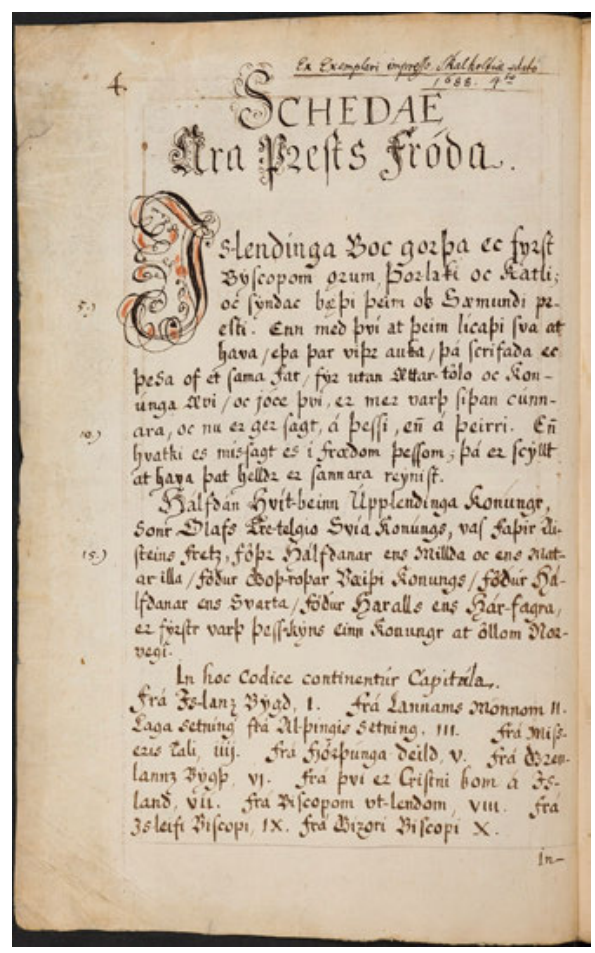

Figure 32: AM 411 fol, p. 4.

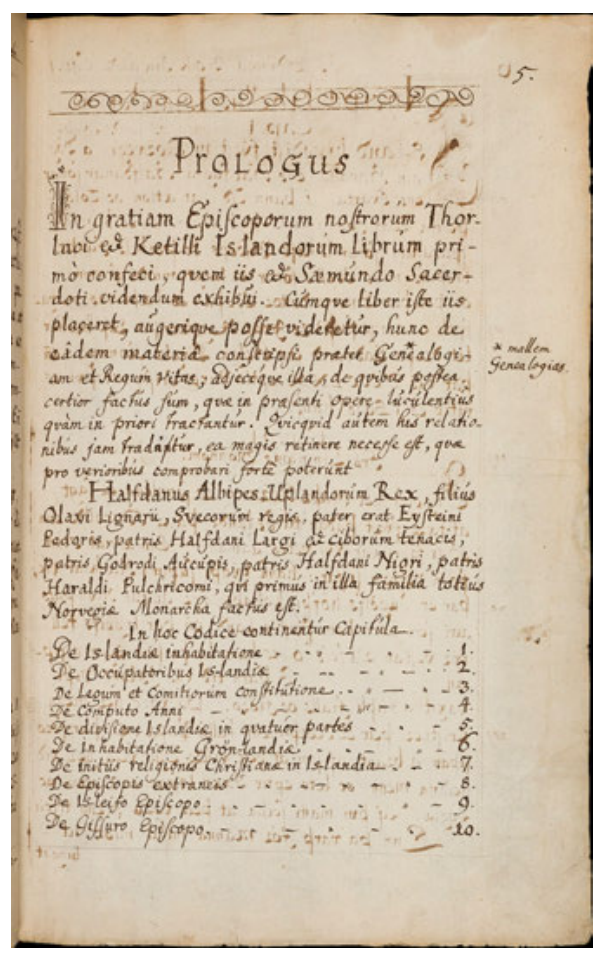

Figure 33: AM 411 fol, p. 5. in Exemplari impresfo 1s-tandico hoc in fine 1 fubjecta funt.

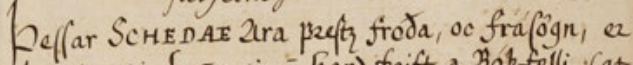
Chrifud eptir fyañs eiguñ Gand-frift a siak-felli (at menn meina) i Jillinga Gollti, af Fóni frefti \& lends ( $\gamma \mathrm{ni}$, AnnoDomini, 1651. Manndaginnnazeftañ qutir Dominicam jübilate.

Fon girlends on p. m. p. I

Figure 34: AM 411 fol, p. 44 (extract showing only the explicit). 
On page 44 (Figure 34), where the register starts - it is adapted but not actually copied from the Skálholt edition - the explicit once written by Jón Erlendsson in AM 113 a fol appears again. The explicit is not translated into Latin in AM 411 fol, and there is no reference to be found to its original source, only to the first printed edition from 1688. Even though the explicit is presented scriptographically, written by Jón Ólafsson úr Grunnavík, the text no longer functions to produce the memory of the existence of a medieval exemplar, as the explicit written by Jón Erlendsson intended to, due to the exclusive reference to the printed version, in which both the per manu propria and the Jón Erlendsson signature became meaningless as credible statements.

In this bilingual edition of AM 411 fol, the body text is equipped with running titles:

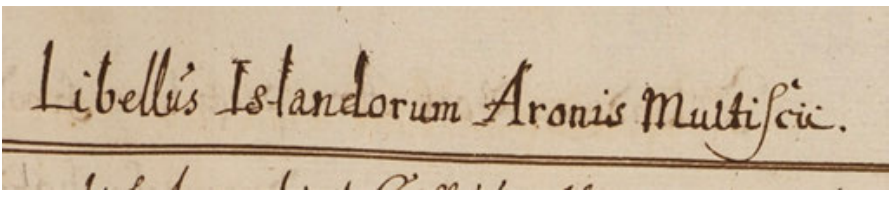

Figure 35: AM 411 fol, p. 23 (extract showing only the running title).

\section{Is-lendinga 30 ok Ara frooda. Cap.1.p.}

Figure 36: AM 411 fol, p. 6 (extract showing only the running title).

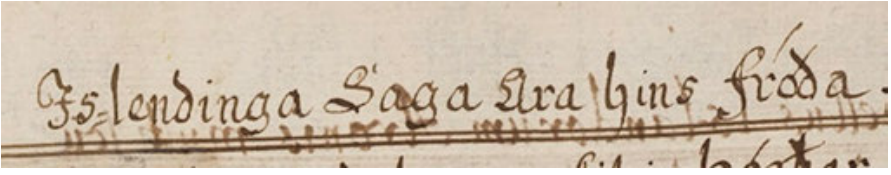

Figure 37: AM 411 fol, p. 16 (extract showing only the running title).

While the Latin titles always refer to Libellus Islandorum Aronis Multiscii (Figure 35), the scribe fiddled around with the Old Norse-Icelandic running titles. They change slightly on almost every page, from Is-lendinga Bók Ara frooða (Figure 36) to Is-lendinga saga Ara hins fróða (Figure 37). As Jón Ólafsson úr Grunnavík was, of course, very proficient with regards to both his skill as a scribe and his knowledge of Árni Magnússon's philological methods and high copying standards, these changes in the running titles do not appear to be made by mistake, but seem to function as an injoke. Still, one can see Jón Ólafsson's awareness of how such running titles are meant 
as paratextual labels for the whole text, or at least the text segment depicted on any given page.

The larger part of AM 411 fol consists of a rearrangement of Árni Magnússon's notes and comments on the text, mainly originating from Árni's notebooks, today known as AM 254 8vo (as discussed above).

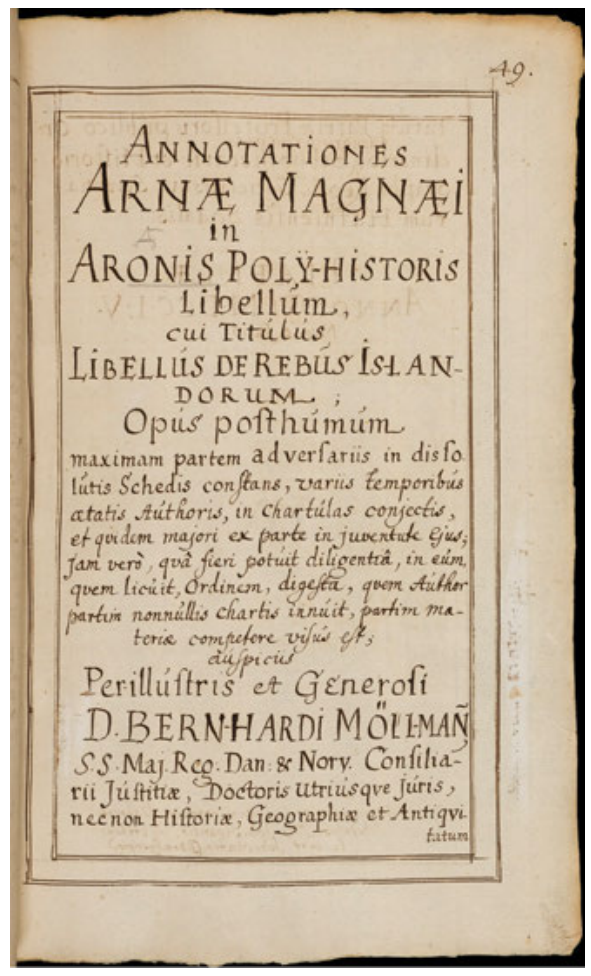

Figure 38: AM 411 fol, p. 49.

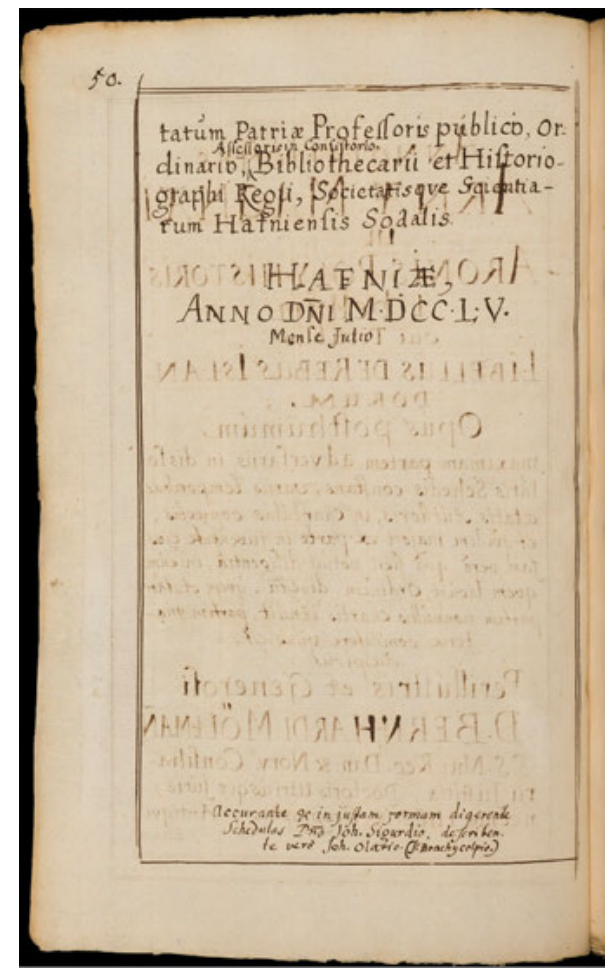

Figure 39: AM 411 fol, p. 50.

The title page (Figure 38) of this second part of the manuscript explicitly refers to the text on which Árni Magnússon's comments are based as Libellus de Rerbus Is-landorum 'The Booklet of Icelandic History', which is declared to be the titulus 'title' of Aronis Poly-Historis Libellum 'The Booklet of Ari the Polymath'. Furthermore, the title page's layout is structured in the fashion of a contemporary printed book, including a special mention and praise of Bernhard Møllmann. The verso page (Figure 39) includes a handwritten imprint with place and date of writing, and instead of the printer, Jón Sigurðsson and Jón Ólafsson úr Grunnavík are mentioned as the scribes. The title page, with its front matter and imprint, thus tries to mimic a printed book (cf. Rösli 2017). The actual beginning of the comments (Figure 40), on the other hand, explicitly refers to Árni Magnússon's autograph (AM 254 8vo) at the top of the page, and thus to the 


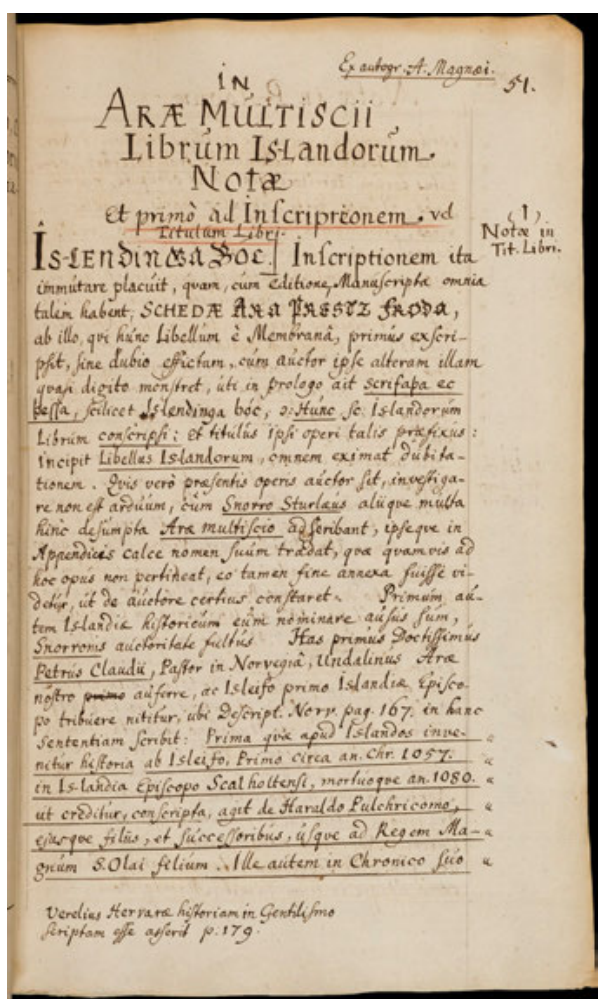

Figure 40: AM 411 fol, p. 51.

medium of the manuscript. Yet the most remarkable thing about this page is that the text or narrative it comments on is called Librum Islandorum as well as Is-lendinga Boc (Figure 40). The comments further explain that there is no doubt about this title or about the author of the text, Ari inn fróði. The commentary, which is compiled on the basis of Árni Magnússon's notes, presents the same arguments for both the authorship of Ari Porgilsson inn fróði and the authenticity of Íslendingabók as those arguments used by scholars today and discussed at the beginning of this chapter.

\section{The stabilization and affirmation of Íslendingabók}

Árni Magnússon's comments and his notion of Schedæ Ara Prests Fróða being the actual Íslendingabók had a huge influence on the two following editions, which were published more than one hundred years after Árni Magnússon's death.

In 1829, Porgeir Guðmundsson and Porsteinn Helgason published the first volume of Îslendinga Sögur. Eptir Gömlum Handritum in Copenhagen (Figure 41). The Fyrsta Bindi (vol. 1) of Îslendínga Sögur contains Îslendíngabók Ara Prests Ens Fróða 


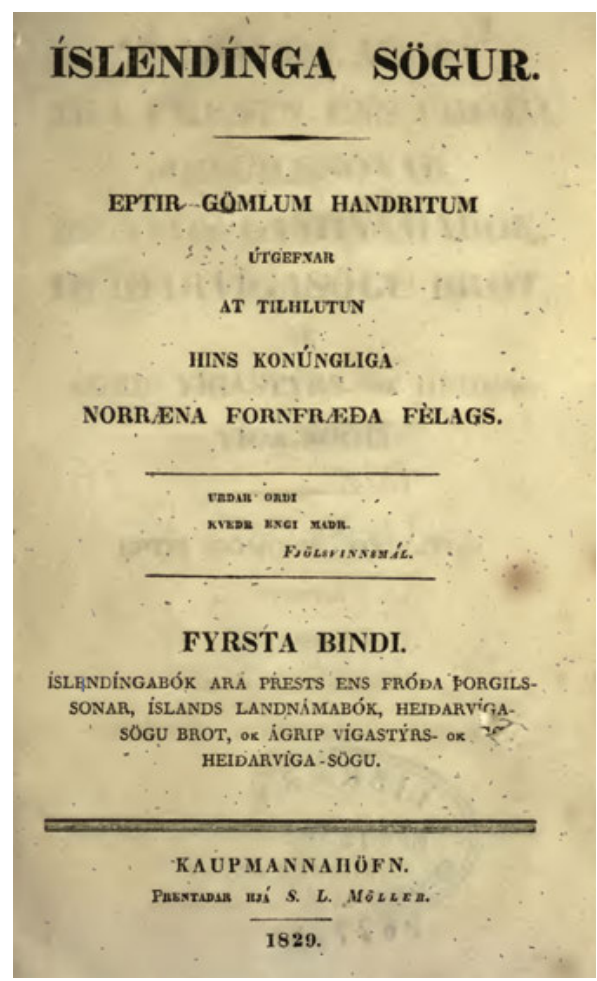

Figure 41: Íslendinga Sögur (1829), book series title page.

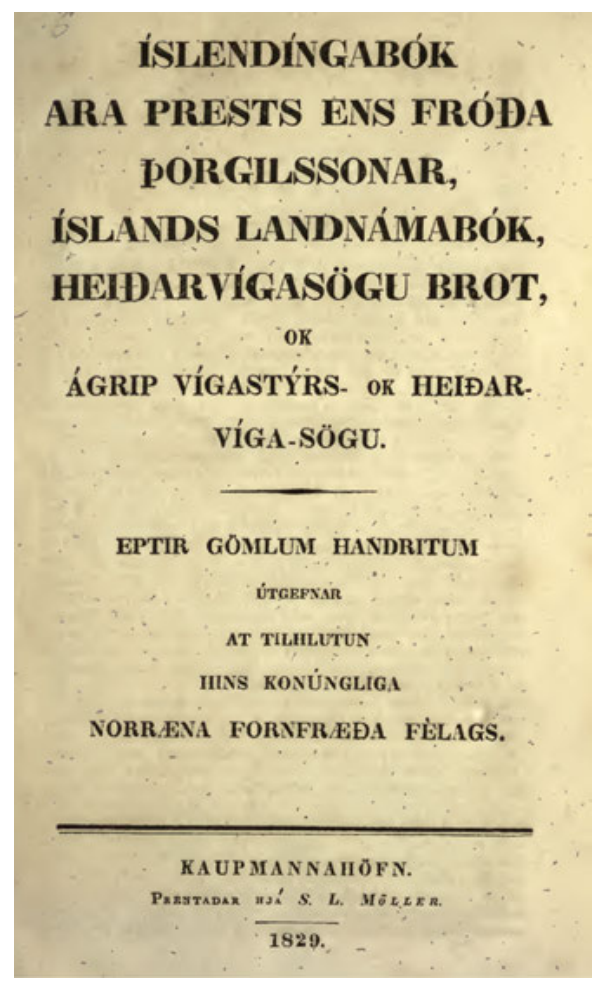

Figure 42: Íslendínga Sögur (1829), title page.

Porgilssonar besides other texts such as Íslands Landnámabók (Figure 42). The juxtaposition of Íslendíngabók and Landnámabók on the title page demonstrates the fact that the intradiegetic Islendinga boc is no longer interpreted as a reference to Landnámabók, and that these two texts are instead single textual entities.

The first page of the body text (Figure 43) depicts the title Íslendinga bók Ara prests ens fróda Porgilssonar followed by the subheading Prologus, which has a footnote marker referring to the fact that the manuscripts transmitted the title of the text as Schedæ Ara prests fróða. Hence, the footnote, at least, still creates a memory of the actual title once used in the oldest extant manuscript of the narrative produced by Jón Erlendsson.

In 1843, the famous politician, historian, and philologist Jón Sigurðsson produced a new edition of the text, published in Copenhagen as part of the first volume of Íslendinga Sögur (Figure 44). In his edition, the title of the narrative in question simply reads Íslendingabóc (Figure 45), which has a note stating again that the manuscripts transmitted the title attributed to the narrative as Schedæ Ara prests fróða. In Jón Sigurðsson's comments on the designation Schedæ Ara prests fróða, the historical 


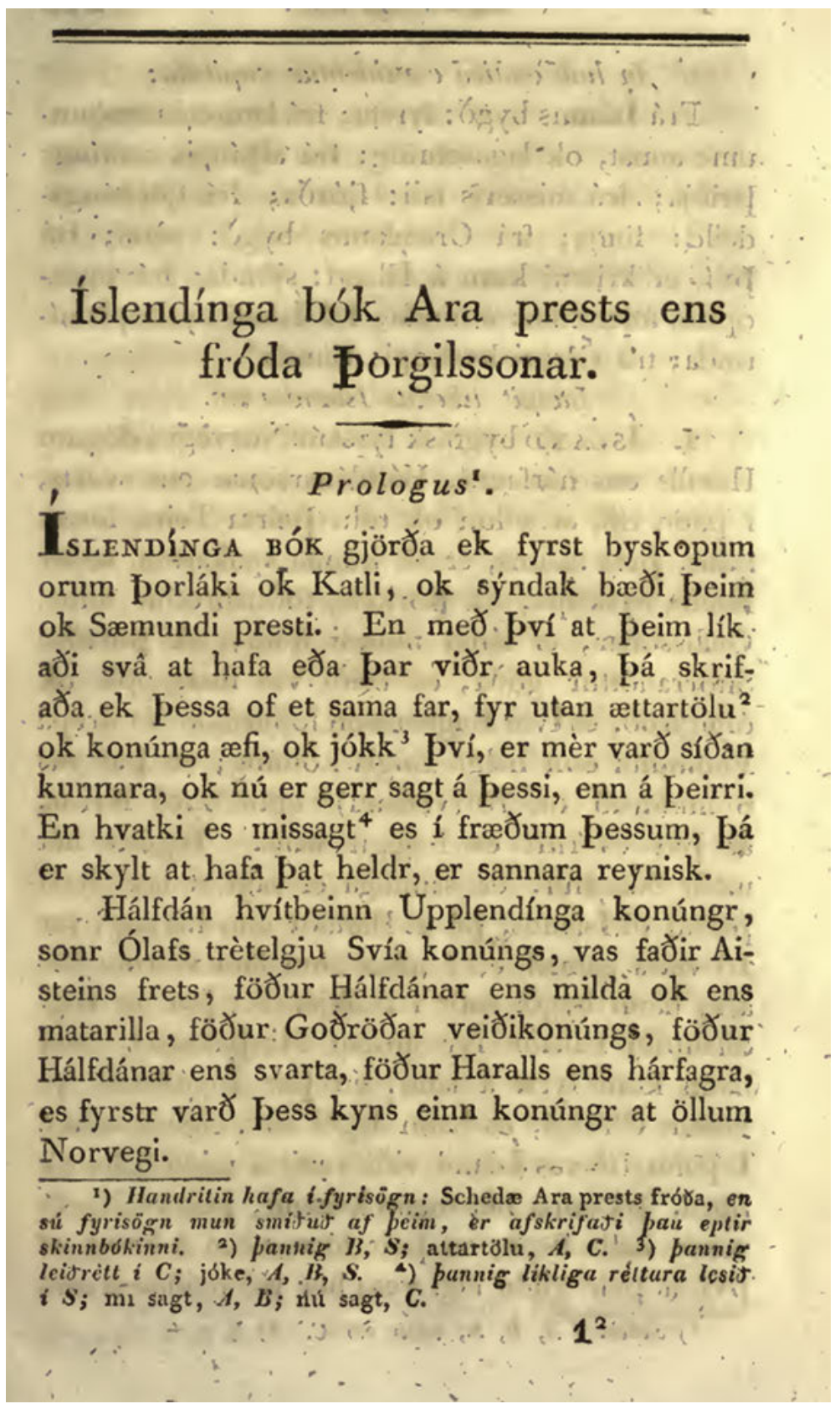

Figure 43: Íslendínga bók Ara prests ens fróda Porgilssonar in Íslendínga Sögur (1829), p. 1. 


\section{ÍSLENDÍNGA SÖGUR,}

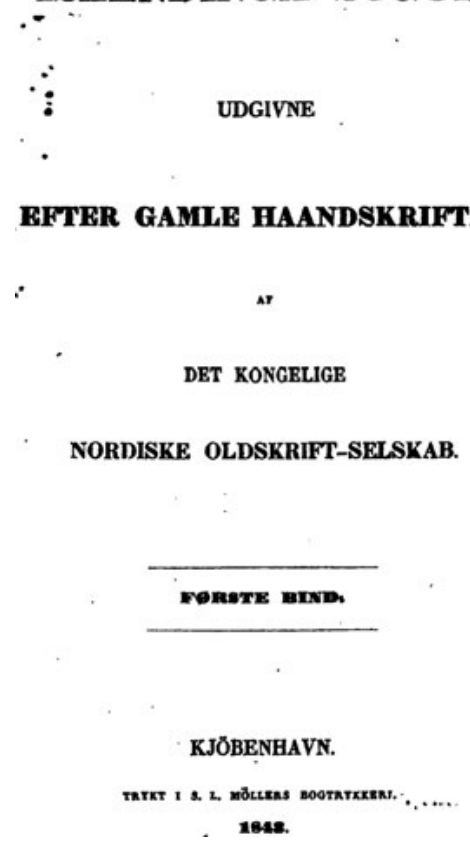

Figure 44: Íslendínga Sögur (1843), front title page.

\section{ISLENDÍNGABÓC ${ }^{2}$.}

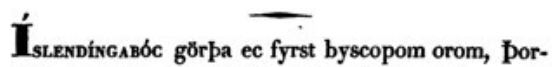
láki oc Catli, oc sýndac bæpi peim oc Sæemundi presti. En mep pví at peim lícapi svà at hafa epa par vipr auca, pá scrifapa ec pessa of et sama far, fyr utan æettartôlo oc conúnga æefi, oc jócc ${ }^{2}$ pví es mer varp sípan cunnara, oc nú es gerr sagt á pessi en á peirri. En hvatki es missagt es.í fropom pessom, pá es scylt at hafa pat beldr, es sannara reynisc. Hálfdan hvítbeinn Upplendíngaconúngr, sonr Olafs tretelgio Sviaconúngs, vas fapir Aisteins frets, fopor Hálfdanar ens milda oc ens matarilla, fópor Gopröpar veipiconúngs, fopor Hálfdanar ens svarta, fopor Haralds ens hárfagra, es fyrstr varp pess kyns einn conúngr at ollom Norvegi.

In hoc codice continentur capitula.

Frá íslands bygp j. Frá landnámsmornnom ij, oc lagasetníng. Frá alpíngis setníng iij. Frá misseristali iiij. Frá fjórpúnga deild v. Frá Groenlands bygp vj. Frá pví es cristni com á ísland vij. Frá

1) Iotedehfor denne Overskrift, som er dannet efter Skrifteto Begyndeloesord, have $A, B, C, S$ S Schedw Ara prests froda, der er en, formodentlig af selve, Afokriveren tilföit, nyere Benernelse. D) d. e. joe ee, saaledes rettet $i C$; joce, $A, B, s$.

\author{
1*
}

Figure 45: Íslendíngabóc in Íslendínga

Sögur (1843), p. 1.

context of the manuscript tradition is totally twisted, as he states that this was a "nyere Benævnelse" (more recent designation).

It probably needs no further explanation that the explicit once written by Jón Erlendsson stating that the text and narrative in AM 113 a fol are based on a medieval manuscript or even on Ari Porgilsson's autograph is not used in either of these two editions from the first part of the nineteenth century. As both these editions tried to produce something similar to a text-critical edition, depicting a supposedly medieval text or even some form of archetype, they had no use for such a sceptical explicit that scrutinized the originality of the narrative in question. 


\section{Conclusion}

In this chapter, I have discussed how Schedæ Ara Prests Fróða, a text from the midseventeenth century, was paratextually modified to become Íslendingabók, a narrative today associated with the first historical writing in Old Norse. It should be emphasized at this point that the question is not whether or not the seventeenth-century text was based on a medieval exemplar, since it is of course possible that a later manuscript is a direct copy of a much earlier one, or whether the narrative conveys historical facts or not, but how the attitude towards this narrative changed during the modifications made.

A narratological reading of the manuscript tradition and transmission of the Schedæ has given evidence that the intradiegetically mentioned Íslendingabók has not been interpreted as the actual text depicted on the folios of the manuscript. By analysing the manuscript tradition, it becomes obvious that the Íslendingabók in the continuous text was never perceived as something accessible by the reader. Consequently, the manuscripts discussed here always evoked a memory of Íslendingabók as a text that only existed as part of the diegesis produced in Schedæ Ara Prests Fróða. At the beginning of the transmission in the second half of the seventeenth century, Schedæ Ara Prests Fróða and its content were authorized through an explicit written by Jón Erlendsson in AM 113 a fol, the oldest accessible manifestation of this narrative. The explicit's purpose, as has been shown, was to authorize the continuous text as a copy of a lost medieval autograph and, in addition, to stylize the text in the manuscript as the carrier of a created cultural memory of the earliest history of Iceland by means of a quasi-medieval narrative, allegedly written by an intertextually well-known character called Ari Porgilsson inn fróði. The same explicit was used in other copies of the text and even in printed editions to create a memory of a supposed medieval manuscript on which the narrative they contained was based. Árni Magnússon realized that the explicit was of uttermost importance in the case of the Schedæ in order to be able to pass the narrative off as medieval even if it was written in seventeenth-century paper manuscripts. Therefore, he copied the explicit into the manuscript AM $113 \mathrm{~b}$ fol, which he considered to be a better copy of the assumed autograph he had never seen. Furthermore, the explicit was completely transferred both into other manuscripts and into the first three printed editions. The fact that even Jón Erlendsson's signature and the abbreviated reference he made to his own handwriting were copied shows how important the explicit was for authorizing the narrative. However, the fact that the actual meaning of the explicit as a form of imprint and the memory generated by it were lost in the process seemed to be of secondary importance.

During the medial transfer of the narrative into print, further paratextual changes can be observed, which were aimed at presenting the Schedæ as a text by Ari Porgilsson inn fróði and as an original report on Icelandic early history. In the printed editions, the narrative is not only integrated into a quasi-national discourse through 
the addition of um Ísland to the title of the text; it is also placed in an intertextual context that increases the national-historical significance of the Schedæ by referring to the fact that the intradiegetically mentioned Íslendingabók actually refers to the Landnámabók or its original manifestation co-authored by Ari.

It was Árni Magnússon's scholarly work on Schedæ Ara Prests Fróða, accompanied by paratextual, medial, scholarly, or editorial and mnemonic changes to the text, which initiated the renaming of the text and its narrative. Only by adapting the title to the otherwise only intradiegetically comprehensible text Íslendingabók, by naming Ari as the official author of this now also extradiegetically accessible Íslendingabók, and by stylizing Ari as the first Icelandic historian did Árni Magnússon create what we know today as Íslendingabók. Since Árni Magnússon's re-evaluation of the Schedæ was done solely on a handwritten basis, it was not until the medial transformation into print that this newly created Íslendingabók with all its quasi-historical, national, and memory-creating implications was able to assert itself. These modifications were finally concluded in the nineteenth century by Icelandic scholarly editors, and the acceptance of the existence of a text called Íslendingabók became reality. This notion of the text is still very much alive today, and scholarly studies are done on this purportedly medieval Íslendingabók, a text supposedly written by an author known as Ari Porgilsson inn fróði, and bearing the title of an intradiegetic text known from a mid-seventeenth-century text called Schedæ Ara Prests Fróða.

\section{Bibliography}

\section{Sources}

Árni Magnússons Levned og Skrifter, 2 vols, ed. Finnur Jónsson. Udgivet af Kommissionen for det Arnamagnæanske legat. Copenhagen: Gyldendal, 1930.

Flateyjarbok. En samling af Norske Konge-sagaer, med indskudte mindre Fortællinger om begivenheder i og udenfor Norege samt Annaler, 3 vols, ed. Guðbrandur Vigfússon. Christiania: Malling, 1860-1868.

Heimskringla 1911 = Snorri Sturluson: Heimskringla, ed. Finnur Jónsson. Copenhagen: G. E. C. Gads Forlag, 1911.

Heimskringla 2016 = Snorri Sturluson: Heimskringla, vol. 1: The Beginnings to Óláfr Tryggvason, trans. Alison Finlay \& Anthony Faulkes, 2nd ed. London: Viking Society for Northern Research, University College London, 2016.

Íslendínga Sögur, ed. Jón Sigurðsson, Copenhagen: Möllers, 1843.

Íslendínga Sögur, ed. Porgeir Guðmundsson \& Porsteinn Helgason, Copenhagen 1829.

Íslendingabók 2006 = Íslendingabók, Kristni saga. The Book of Icelanders. The Story of Conversion, trans. by Sîan Grønlie. London: Viking Society for Northern Research, University College London, 2006.

Íslendingabók Ara Fróða. AM $113 a$ and 113 b, fol, facsimile edition with an introduction by Jón Jóhannesson. Íslenzk Handrit, vol. 1. Reykjavík: Lithoprent and University of Iceland, 1956. 
Íslendingabók, Landnámabók, 2 vols, ed. Jakob Benediktsson. Ísenzk Fornrit 1. Reykjavík: Hið Íslenzka Fornritafélag, 1968.

Landnámabók 1968, see Íslendingabók, Landnámabók.

Landnámabók. Ljósprentun Handrita, ed. and intr. by Jakob Benediktsson. Reykjavík: Stofnun Árna

Magnússonar, 1974.

Saga Óláfs Tryggvasonar af Oddr Snorrason Munk, ed. Finnur Jónsson. Copenhagen: G. E. C. Gads Forlag, 1932.

Sagan Landnama. Um fyrstu bygging Islands af Nordmønnum, ed. Pórður Porláksson, Skálholt 1688.

Schedae, seu Libellus de Is-landia, ed. Andreas Bussæus, Copenhagen 1733.

Schedæ Ara Prests Fróða Um Island, ed. Pórður Porláksson, Skálholt 1688.

Schedæ de Islandia, ed. Christen Worm, Oxford 1716.

Skarðsárbók. Landnámabók Björns Jónssonar á Skarðsá, ed. Jakob Benediktsson. Reykjavík: Háskóli Îslands, 1958.

The Book of Settlements. Landnámabók, trans. and intr. Hermann Pálsson \& Paul Edwards. Winnipeg: University of Manitoba Press, 1972.

The book of the Icelanders (Islendingabók): Ari porgilsson, ed., trans., and com. by Halldór Hermannsson. Ithaca: Cornell University Library, 1930.

\section{Literature}

Assmann, Jan. 2011. Cultural Memory and Early Civilization. Writing, Remembrance, and Political Imagination. Cambridge: Cambridge University Press.

Assmann, Jan. 2008. "Communicative and Cultural Memory." In: Cultural Memory Studies. An International and Interdisciplinary Handbook, ed. Astrid Erll \& Ansgar Nünning, 109-118. Berlin: de Gruyter.

Björn Sigfússon. 1944. Um Íslendingabók. Reykjavík: Víkingsprent H. F.

Bumke, Joachim. 1996. "Der unfeste Text: Überlegungen zur Überlieferungsgeschichte und Textkritik der höfischen Epik im 13. Jahrhundert". In: "Aufführung" und "Schrift" in Mittelalter und Früher Neuzeit, ed. Jan-Dirk Müller, 118-129. Stuttgart: Metzler.

Clunies Ross, Margaret. 1998. Prolonged Echoes. Old Norse myths in medieval Northern society. Vol. 2 - The reception of Old Norse myths in medieval Iceland. Odense: Odense University Press.

Clunies Ross, Margaret. 1994. Prolonged Echoes. Old Norse myths in medieval Northern society. Vol. 1 - The Myths. Odense: Odense University Press.

Genette, Gérard. 1997. Paratexts. Thresholds of Interpretation. Trans. Jane E. Lewin. Cambridge: Cambridge University Press.

Genette, Gérard. 1980. Narrative Discourse. An Essay in Method. Trans. Jane E. Lewin. Ithaca: Cornell University Press.

Glauser, Jürg, ed. 2016. Skandinavische Literaturgeschichte. Stuttgart: Metzler.

Helgi 1varsson. 2007. "Sr. Jón Erlendsson handritaskrifari î Villingaholti.” Arnesingur 8: 157-170.

Hermann, Pernille. 2005. "Spatial and Temporal Perspectives in Íslendingabók: Historiography and Social Structures." Viking and Medieval Scandinavia 1: 73-89.

Hermann, Pernille. 2007. "Íslendingabók and History." In: Reflections on Old Norse Myths, ed. Pernille Hermann, et al., 18-32. Turnhout: Brepols.

Hreinn Benediktsson. 1965. Early Icelandic Script as Illustrated in Vernacular Texts from the Twelfth and Thirteenth Centuries. Íslenzk Handrit, Series in Folio, Vol. 2. Reykjavík: The Manuscript Institute of Iceland. 
Johansson, Karl G. 1997. Studier i Codex Wormianus. Skrifttradition och avskriftsverksamhet vid ett isländskt skriptorium under 1300-talet. Göteborg: University of Gothenburg.

Jónas Kristjánsson. 1997 [1988]. Eddas and Sagas. Iceland's Medieval Literature. Trans. Peter Foote. Reykjavík: Hið íslenska bókmenntafélag.

Lindow, John. 1997. “Íslendingabók and Myth.” Scandinavian Studies 69 (4): 454-464.

Margrét Eggertsdóttir. 2010. "Handritamiðstöðin í Skálholti." In: Menntun og menning í Skálholtsstifti 1620-1730, ed. Kristinn Ólason, 79-88. Skálholt: Grettisakademía.

Már Jónsson. 2012. Arnas Magnæanus Philologus (1663-1730). Odense: University Press of Southern Denmark.

Mundal, Else. 2012. "Modes of Authorship and Types of Text in Old Norse Culture." In: Modes of Authorship in the Middle Ages, ed. Slavica Rankovic, 211-226. Toronto: Toronto Pontifical Institute of Medieval Studies.

Obermaier, Sabine. 2004 Das Fabelbuch als Rahmenerzählung. Intertextualität und Intratextualität als Wege zur Interpretation des Buchs der Beispiele der alten Weisen Antons von Pforr. Beihefte zu Euphorion, Zeitschrift für Literaturgeschichte 48. Heidelberg: Winter.

Plett, Heinrich F. 1991. “Intertextualities.” In: Intertextuality, ed. Heinrich F. Plett, 3-29. Berlin: de Gruyter.

Puckett, Kent. 2016. Narrative Theory. A Critical Introduction. Cambridge: Cambridge University Press.

Rösli, Lukas. 2018. “Manuscripts.” In: Handbook of Pre-Modern Nordic Memory Studies. Interdisciplinary Approaches, ed. Jürg Glauser, Pernille Hermann \& Stephen A. Mitchell, 2 vols, 406-413. Berlin: de Gruyter.

Rösli, Lukas. 2017. “'Prentuð i Kaupenh.' - Das Mimikry des Druckvermerks in der Handschrift íB 299 4to." In: Skandinavische Schriftlandschaften. Festschrift für Jürg Glauser, ed. Kate Heslop, Klaus Müller-Wille, Anna Katharina Richter \& Lukas Rösli, 212-216. Tübingen: Francke.

Rothe, Arnold. 1986. Der literarische Titel. Funktionen, Formen, Geschichte. Frankfurt am Main: Vittorio Klostermann.

Simek, Rudolf \& Hermann Pálsson. 2007 [1987]. Lexikon der altnordischen Literatur. Stuttgart: Kröner.

Sveinbjörn Rafnsson. 2001. Sögugerd Landnámabókar. Um íslenska sagnaritun á 12. og 13. öld. Reykjavík: Sagnfræðistofnun Háskóla Íslands.

Sveinbjörn Rafnsson. 1974. Studier i Landnámabók. Kritiska bidrag til den isländska fristatstidens historia. Lund: C. W. K. Gleerup.

Turville-Petre, Gabriel. 1967 [1953]. Origins of Icelandic Literature. Oxford: Oxford University Press. 
